Check for updates

Cite this: RSC Adv., 2017, 7, 33975

\title{
Novel BODIPY dyes with electron donor variety for dye-sensitized solar cells $\uparrow$
}

\author{
Junxu Liao, ${ }^{\text {ab }}$ Hongbin Zhao, ${ }^{\text {a }}$ Yongjun Xu, D ${ }^{* a}$ Weinan Zhou, $^{a}$ Fei Peng, ${ }^{a}$ \\ Yong Wang ${ }^{a}$ and Yutang Fang ${ }^{b}$
}

Four new donor- $\pi$-acceptor $(D-\pi-A)$ structured organic sensitizers (CB1-4), with $N$-octyl or $N$ methoxyphenyl carbazole connected to a 2-cyanoacrylate BODIPY module through their 2 or 3positions, were designed and synthesized for application in dye-sensitized solar cells (DSSCs). The photophysical and electrochemical properties were systematically studied and their performances as sensitizers in DSSCs were comparatively investigated. The structure-property relationship suggests that the electron-donating ability and substitution positions of the donor have a significant effect on these dyes' electronic and photovoltaic properties. Electron-rich $N$-methoxyphenyl carbazole as a donor and substitution at the 2-position shows a positive influence on the efficiency of DSSCs. Consequently, CB4, with the combination of these advantages, presents the broadest $(300-650 \mathrm{~nm}$ ) and strongest absorption profile with a high extinction coefficient $\left(1.71 \times 10^{5} \mathrm{M}^{-1} \mathrm{~cm}^{-1}\right)$ and the best photovoltaic performance with a short circuit photocurrent density of $10.20 \mathrm{~mA} \mathrm{~cm}{ }^{-2}$, an open circuit voltage of $600 \mathrm{mV}$, and a fill factor of 0.7 , corresponding to a fairly good overall conversion efficiency of $4.28 \%$ under AM 1.5 irradiation $\left(100 \mathrm{~mW} \mathrm{~cm}^{-2}\right)$.

Received 19th April 2017

Accepted 16th June 2017

DOI: 10.1039/c7ra04402j

rsc.li/rsc-advances
Boron dipyrromethene (BODIPY) have attracted numerous explorations in many potential applications owing to their intensive absorption/emission in the visible and near-IR ranges, high fluorescence quantum yield, long excited-state lifetime, excellent thermal/photochemical stability and good solubility. ${ }^{25-27}$ Possessing all these characteristics, BODIPY dyes have emerged as promising photo sensitizers in DSSCs. ${ }^{28-31}$ However, the power efficiency of BODIPY-based DSSCs $(6.06 \%)^{31}$ has lagged behind porphyrin-based counterparts $(13 \%){ }^{7}$ progress is being made in order to improve their efficiencies. Recent studies have focused on the development of BODIPY dyes with a donorchromophore-acceptor (D-BODIPY-A) molecular architecture to enhance the light-harvesting ability. ${ }^{32,33}$ In this system, an appropriate donor and suitable connect manner are the key factors for achieving high power efficiency. Mao and coworkers demonstrated that the D- $\pi-\mathrm{A}$ type BODIPY dyes modified with 2,6-donor/acceptor groups are promising photosensitizers in the DSSCs, with relatively high efficiency of nearly $5.31 \% .{ }^{33}$ From the donor attention, carbazole derivative is good compound with excellent photoelectric properties. It has strong absorption and emission properties of spectrum, high hole transport capacity and wide band gap, have a wide range of applications in the field of photoelectric materials. ${ }^{34,35}$ In view of the photoelectric properties of this kind of materials to highlight, the combination of BODIPY and carbazole and used in dye-sensitised cells caused our research interest.

Base on the above consideration, to gain insight into the influence of molecular structure on their optoelectronic

\footnotetext{
${ }^{a}$ School of Chemical Engineering and Energy Technology, Dongguan University of Technology, Dongguan 523808, People's Republic of China. E-mail: zhaohbhanlf@ 163.com; hnllxyj@126.com; Fax: +86-769-2286-2601; +86-769-2286-2605; Tel: +86158-1831-8389; +86-139-2583-6155

${ }^{b}$ School of Chemistry and Chemical Engineering, South China University of Technology, Guangzhou 510641, People's Republic of China

$\dagger$ Electronic supplementary information (ESI) available: ${ }^{1} \mathrm{H}$ NMR and ${ }^{13} \mathrm{C}$ NMR spectra and mass spectra of all unknown compounds. See DOI: $10.1039 / \mathrm{c} 7 \mathrm{ra} 04402 \mathrm{j}$
} 


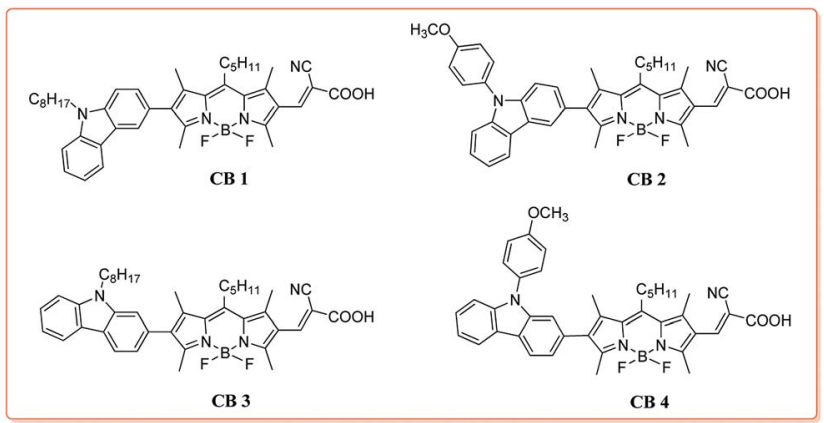

Chart 1 Molecular structures of BODIPY dyes CB1-4.

properties and explore good carbazole-BODIPY conjugates for photovoltaic applications, in this contribution, we designed and synthesized four novel carbazole-BODIPY based dyes (CB1-4, Chart 1) with carbazole derivatives unit as the electron donor and cyanoacetic acid as an electron receptor at 2 and 6 positions of BODIPY core, respectively. The optical properties, electrochemical behavior, density functional theory calculations and photovoltaic performances of these sensitizers were systematically investigated and the impact of donor's electron donating ability and substitute positions on their electronic and photovoltaic properties were also comparatively studied. We expect to illuminate the structureproperty relationship of these BODIPY-based sensitizers and to develop an excellent photoelectric material.

\section{Experimental}

\subsection{Materials and measurements}

All chemicals were purchased from Aldrich or Aladdin and used without further purification. Tetrahydrofuran and 1,4-dioxane was distilled over sodium. Other materials were common commercial level and used as received. Compounds $\mathbf{3 a - d}$ were synthesized according to the reported procedures. ${ }^{36-38}$ All chromatographic separations were carried out on silica gel column (300-400 mesh).

${ }^{1} \mathrm{H}$ NMR and ${ }^{13} \mathrm{C}$ NMR spectra were recorded on a Bruker Avance spectrometer (400 and $101 \mathrm{MHz}$, respectively) with TMS as the internal standard. Matrix-assisted laser desorption/ ionisation time of flight mass spectra (MALDI-TOF-MS) were acquired on a Bruker Ultraflex-II spectrometer. Absorption spectra were measured on an SHIMADZU UV-2550 UV-Vis spectrophotometer and emission spectra were obtained by using a Hitachi F-4500 instrument. Cyclic voltammetry (CV) was determined with a CHI660E electrochemical workstation utilizing a three electrode cell consisting of a gold electrode (working electrode), platinum wire (auxillary electrode) and $\mathrm{Ag} /$ $\mathrm{AgCl}$ electrode (reference electrode). The experiment was carried out in dry $\mathrm{CH}_{2} \mathrm{Cl}_{2}$ under $\mathrm{Ar}$ atmosphere condition using $0.1 \mathrm{M}$ tetrabutylammonium hexafluorophosphate $\left(n-\mathrm{Bu}_{4} \mathrm{NPF}_{6}\right)$ as supporting electrolyte.

\subsection{Fabrication and characterization of DSSCs}

Fluorine-doped $\mathrm{SnO}_{2}$ conducting glass (FTO) were cleaned and immersed in aqueous $40 \mathrm{mM} \mathrm{TiCl}_{4}$ solution at $70{ }^{\circ} \mathrm{C}$ for $30 \mathrm{~min}$, then washed with deionized water and ethanol, sintered at $450{ }^{\circ} \mathrm{C}$ for $30 \mathrm{~min}$. The $\mathrm{TiO}_{2}$ suspension was prepared from P25 (Degussa AG, Germany) ${ }^{39}$ and $1 \mathrm{wt} \%$ magnesium acetate solution $^{40}$ on following a literature procedure. Then the paste was deposited onto the FTO glass by blade coating. Subsequently, a $3 \mu \mathrm{m}$ thick $200 \mathrm{~nm}$ particle sized $\mathrm{TiO}_{2}$ scattering layer was deposited again by blade coating. The $\mathrm{TiO}_{2}$-coated FTO glass was sintered at $450{ }^{\circ} \mathrm{C}$ for $30 \mathrm{~min}$, then treated with $\mathrm{TiCl}_{4}$ solution at $70{ }^{\circ} \mathrm{C}$ for $30 \mathrm{~min}$ and calcined at $450{ }^{\circ} \mathrm{C}$ for $30 \mathrm{~min}$ again. After the film was cooled to room temperature, it was immersed into $0.5 \mathrm{mM}$ dye solution in the dark overnight. The sensitized electrode was then rinsed with ethanol and dried. A drop of electrolyte was deposited onto the surface of the electrode and a Pt foil counter electrode was clipped onto the top of the $\mathrm{TiO}_{2}$ electrode to assemble a DSSC for photovoltaic performance measurements. The electrolyte consisted of $0.5 \mathrm{M} \mathrm{LiI}$, $0.05 \mathrm{M} \mathrm{I}_{2}, 0.1 \mathrm{M}$ guanidinium thiocyanate, $0.6 \mathrm{M}$ PMII and $0.5 \mathrm{M}$ 4-tert-butylpyridine (TBP) in 3-methoxypropionitrile and the efficient irradiated area of the cell was $0.2 \mathrm{~cm}^{-2}$. The current density-voltage $(J-V)$ curves were measured by a Keithley 2602 Source Meter under $100 \mathrm{Mw} \mathrm{cm}^{-2}$ standard AM $1.5 \mathrm{G}$ spectrum using a Sol 3A Oriel solar simulator. The incident light intensity was calibrated using a standard $\mathrm{Si}$ solar cell. The power conversion efficiency $(\eta)$ of the DSSC is calculated from the short-circuit photo-current $\left(J_{\mathrm{sc}}\right)$, the open-circuit photovoltage $\left(V_{\text {oc }}\right)$, the fill factor $(\mathrm{FF})$ and the intensity of the incident light $\left(P_{\text {in }}\right)$ according to the following equation:

$$
\eta=\frac{J_{\mathrm{sc}}\left(\mathrm{mA} \mathrm{cm}^{-2}\right) \times V_{\mathrm{oc}}(V) \times \mathrm{FF}}{P_{\mathrm{in}}\left(\mathrm{mW} \mathrm{cm} \mathrm{cm}^{-2}\right)}
$$

\subsection{Synthesis procedures and characterization data of new compounds}

\subsubsection{Synthesis of $2 \mathrm{a}-\mathrm{b}$}

3-Bromo-9-octyl-9H-carbazole $2 \boldsymbol{a}$. As the procedure shown in Scheme 1, treated 9-octyl-9H-carbazole $1 \mathrm{a}(2.8 \mathrm{~g}, 10 \mathrm{mmol})$ in dry DMF $(50 \mathrm{~mL})$ at $-20{ }^{\circ} \mathrm{C}$ under argon atmosphere with NBS (1.96 g, $11 \mathrm{mmol}$ ), and the mixture was stirred at this temperature for $4 \mathrm{~h}$. Then, the reaction mixture was brought to room temperature, and poured into water and extracted with ethyl acetate. The organic layer was dried over anhydrous $\mathrm{Na}_{2} \mathrm{SO}_{4}$, and evaporated to dryness. The residue was purified by silica gel column chromatography using petroleum ether as eluent, afforded $2 \mathrm{a}$ as white solid (2.56 g, yield: $72 \%$ ). ${ }^{1} \mathrm{H}$ NMR (400 $\left.\mathrm{MHz} \mathrm{CDCl}_{3}\right) \delta 8.21(\mathrm{~s}, 1 \mathrm{H}), 8.05(\mathrm{~d}, J=6.1 \mathrm{~Hz}, 1 \mathrm{H}), 7.55-7.52$ $(\mathrm{m}, 1 \mathrm{H}), 7.48(\mathrm{~d}, J=7.2 \mathrm{~Hz}, 1 \mathrm{H}), 7.42-7.39(\mathrm{~m}, 1 \mathrm{H}), 7.27(\mathrm{t}, J=$ $12.0 \mathrm{~Hz}, 2 \mathrm{H}), 4.28-4.25(\mathrm{~m}, 2 \mathrm{H}), 1.87-1.82(\mathrm{~m}, 2 \mathrm{H}), 1.46-1.23$ $(\mathrm{m}, 10 \mathrm{H}), 0.85(\mathrm{t}, J=6.1 \mathrm{~Hz}, J=6.8 \mathrm{~Hz}, 3 \mathrm{H})$.

3-Bromo-9-(4-methoxyphenyl)-9H-carbazole $2 \mathrm{~b}$. Treated 9-(4methoxyphenyl)-9H-carbazole $\mathbf{1 b}(2.71 \mathrm{~g}, 10 \mathrm{mmol})$ in dry DMF $(50 \mathrm{~mL})$ at $0{ }^{\circ} \mathrm{C}$ under argon atmosphere with NBS (1.96 g, 11 $\mathrm{mmol}$ ), and the mixture was stirred at room temperature for $12 \mathrm{~h}$. Then, the reaction mixture was poured into water and extracted with ethyl acetate. The organic layer was dried over anhydrous $\mathrm{Na}_{2} \mathrm{SO}_{4}$, and evaporated to dryness. The residue was purified by silica gel column chromatography using petroleum 


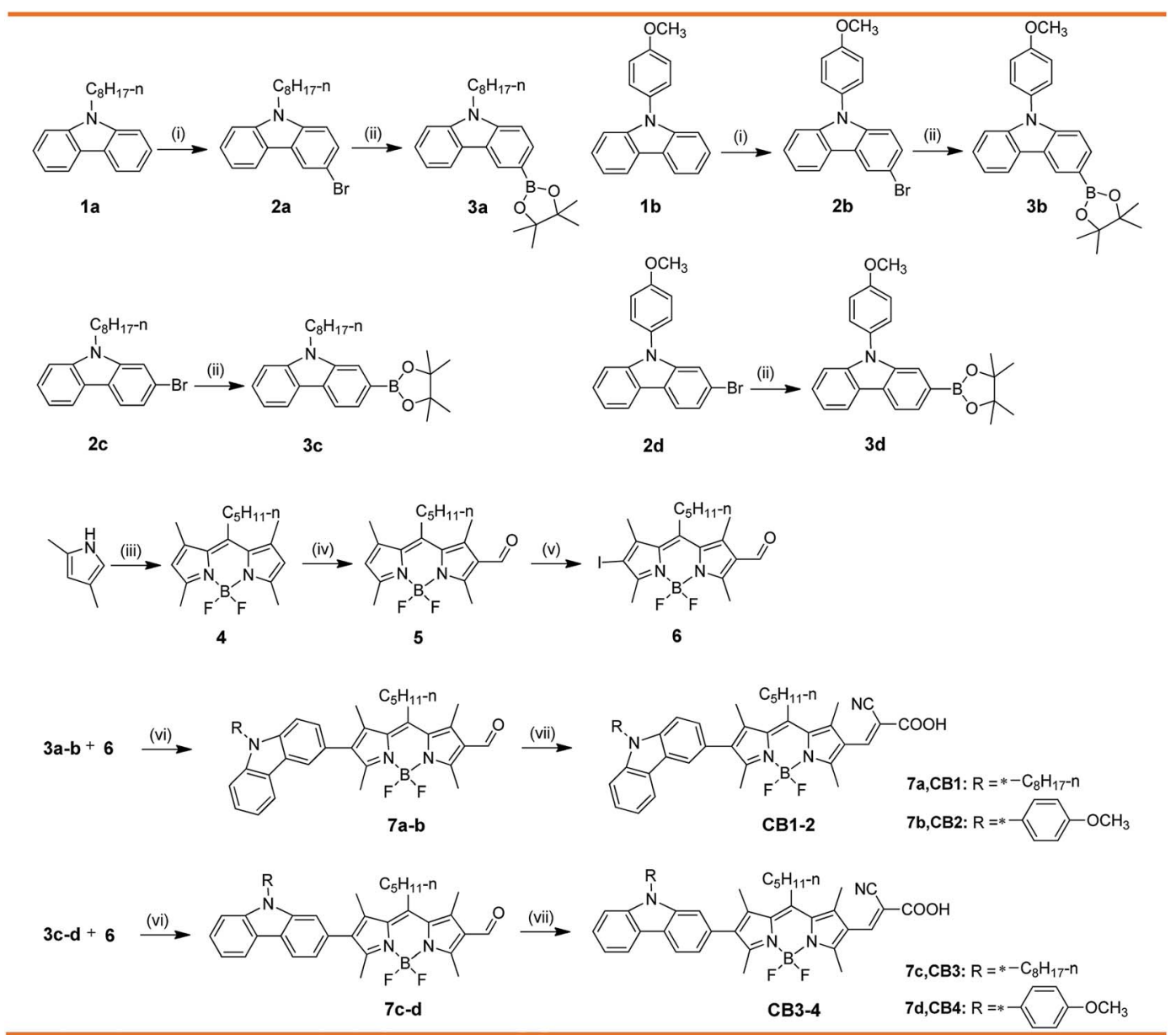

Scheme 1 The synthetic routes for dyes CB1-4. (i) NBS, DMF; (ii) $\mathrm{B}_{2} \mathrm{Pin}_{2}, \mathrm{KOAc}, \mathrm{Pd}(\mathrm{dppf}) \mathrm{Cl}_{2}, 1,4$-dioxane; (iii) $n$-hexanoyl chloride, $\mathrm{CH}_{2} \mathrm{Cl}_{2}$, then $\mathrm{Et}_{3} \mathrm{~N}, \mathrm{BF}_{3} \cdot \mathrm{Et}_{2} \mathrm{O}$, toluene; (iv) $\mathrm{POCl}_{3}, \mathrm{DMF}, \mathrm{ClCH}_{2} \mathrm{CH}_{2} \mathrm{Cl}$; (v) ICl, DMF, $\mathrm{MeOH}$; (vi) $\mathrm{Pd}\left(\mathrm{PPh}_{3}\right)_{4}, \mathrm{~K}_{2} \mathrm{CO}_{3}$, THF; (vii) cyanoacetic, piperidine, $\mathrm{CHCl}_{3}$ / $\mathrm{CH}_{3} \mathrm{CN}$.

ether as eluent, afforded $\mathbf{2 b}$ as white solid $(3.1 \mathrm{~g}$, yield: $90 \%) .{ }^{1} \mathrm{H}$ NMR $\left(400 \mathrm{MHz}, \mathrm{CDCl}_{3}\right) \delta 8.22(\mathrm{~d}, J=21.4 \mathrm{~Hz}, 1 \mathrm{H}), 8.08(\mathrm{~d}, J=$ $6.8 \mathrm{~Hz}, 1 \mathrm{H}), 7.48-7.39(\mathrm{~m}, 4 \mathrm{H}), 7.33-7.27(\mathrm{~m}, 2 \mathrm{H}), 7.19(\mathrm{~d}, J=$ $7.2 \mathrm{~Hz}, 1 \mathrm{H}), 7.11(\mathrm{~d}, J=7.0 \mathrm{~Hz}, 2 \mathrm{H}), 3.92(\mathrm{~s}, 3 \mathrm{H})$.

2.3.2. General procedure for the preparation of $3 a-d$. To the solution of bromo-compounds $(10 \mathrm{mmol})$ and $4,4,4^{\prime}, 4^{\prime}, 5,5,5^{\prime}, 5^{\prime}$-octamethyl-2,2'-bi(1,3,2-di-oxaborolane) (12 $\mathrm{mmol})$ in diethylene dioxide $(100 \mathrm{~mL})$ was added $\mathrm{Pd}(\mathrm{dppf}) \mathrm{Cl}_{2}$ $(0.5 \mathrm{mmol})$ and potassium acetate $(30 \mathrm{mmol})$. The mixture was stirred at $90{ }^{\circ} \mathrm{C}$ under argon atmosphere for $24 \mathrm{~h}$. The reaction mixture was cooled to room temperature and poured to water $(100 \mathrm{~mL})$, extracted with ethyl acetate, the organic layer was washed with brine for several times, dried over anhydrous $\mathrm{Na}_{2} \mathrm{SO}_{4}$, and evaporated to dryness. The corresponding boron ester was obtained by column chromatography on silica gel using petroleum ether and ethyl acetate.

9-Octyl-3-(4,4,5,5-tetramethyl-1,3,2-dioxaborolan-2-yl)-9H-carbazole $3 a$. Yellow oil, yield: $82 \% . R_{\mathrm{f}}=0.35,(\mathrm{PE}: \mathrm{EA}=20: 1) .{ }^{1} \mathrm{H}$ NMR $\left(400 \mathrm{MHz}, \mathrm{CDCl}_{3}\right) \delta 8.60(\mathrm{~s}, 1 \mathrm{H}), 8.13(\mathrm{~d}, J=7.6 \mathrm{~Hz}, 1 \mathrm{H})$, $7.92(\mathrm{~d}, J=8.1 \mathrm{~Hz}, 1 \mathrm{H}), 7.45(\mathrm{~d}, J=7.3 \mathrm{~Hz}, 1 \mathrm{H}), 7.40(\mathrm{t}, J=9.5 \mathrm{~Hz}$, $2 \mathrm{H}), 7.23(\mathrm{~d}, J=7.0 \mathrm{~Hz}, 1 \mathrm{H}), 4.30(\mathrm{t}, J=6.9 \mathrm{~Hz}, 2 \mathrm{H}), 1.90-1.86(\mathrm{~m}$, $2 \mathrm{H}), 1.44(\mathrm{~s}, 12 \mathrm{H}), 1.36-1.28(\mathrm{~m}, 10 \mathrm{H}), 0.85(\mathrm{t}, J=13.6 \mathrm{~Hz}, 3 \mathrm{H})$.
9-(4-Methoxyphenyl)-3-(4,4,5,5-tetramethyl-1,3,2-dioxaborolan2-yl)-9H-carbazole $3 b$. White solid, yield: $84 \% . R_{\mathrm{f}}=0.35$, (PE : EA $=20: 1) .{ }^{1} \mathrm{H}$ NMR $\left(400 \mathrm{MHz}, \mathrm{CDCl}_{3}\right) \delta 8.26-8.24(\mathrm{~m}, 1 \mathrm{H}), 8.18$ $(\mathrm{d}, J=6.8 \mathrm{~Hz}, 1 \mathrm{H}), 7.48-7.45(\mathrm{~m}, 4 \mathrm{H}), 7.31-7.28(\mathrm{~m}, 2 \mathrm{H}), 7.19(\mathrm{~d}$, $J=7.2 \mathrm{~Hz}, 1 \mathrm{H}), 7.11(\mathrm{~d}, J=7.1 \mathrm{~Hz}, 2 \mathrm{H}), 3.92(\mathrm{~m}, 3 \mathrm{H}), 1.36(\mathrm{~s}$, $12 \mathrm{H})$.

9-Octyl-2-(4,4,5,5-tetramethyl-1,3,2-dioxaborolan-2-yl)-9H-carbazole 3c. Yellow oil, yield: $80 \% . R_{\mathrm{f}}=0.35,(\mathrm{PE}: \mathrm{EA}=20: 1) .{ }^{1} \mathrm{H}$ NMR $\left(400 \mathrm{MHz}, \mathrm{CDCl}_{3}\right) \delta 8.60(\mathrm{~s}, 1 \mathrm{H}), 8.13(\mathrm{~d}, J=7.6 \mathrm{~Hz}, 1 \mathrm{H})$, $7.92(\mathrm{~d}, J=8.1 \mathrm{~Hz}, 1 \mathrm{H}), 7.45(\mathrm{~d}, J=7.3 \mathrm{~Hz}, 1 \mathrm{H}), 7.40(\mathrm{t}, J=9.5 \mathrm{~Hz}$, $2 \mathrm{H}), 7.23(\mathrm{~d}, J=7.0 \mathrm{~Hz}, 1 \mathrm{H}), 4.30(\mathrm{t}, J=6.9 \mathrm{~Hz}, 2 \mathrm{H}), 1.90-1.86(\mathrm{~m}$, $2 \mathrm{H}), 1.44(\mathrm{~s}, 12 \mathrm{H}), 1.36-1.28(\mathrm{~m}, 10 \mathrm{H}), 0.85(\mathrm{~m}, J=13.6 \mathrm{~Hz}, 3 \mathrm{H})$. 9-(4-Methoxyphenyl)-2-(4,4,5,5-tetramethyl-1,3,2-dioxaborolan2-yl)-9H-carbazole $3 d$. White solid, yield: $79 \% . R_{\mathrm{f}}=0.35$, (PE : EA $=20: 1) .{ }^{1} \mathrm{H}$ NMR $\left(400 \mathrm{MHz}, \mathrm{CDCl}_{3}\right) \delta 8.19-8.13(\mathrm{~m}, 2 \mathrm{H}), 7.80-$ $7.72(\mathrm{~m}, 2 \mathrm{H}), 7.46(\mathrm{~d}, J=8.7 \mathrm{~Hz}, 2 \mathrm{H}), 7.41(\mathrm{~d}, J=7.4 \mathrm{~Hz}, 1 \mathrm{H})$, $7.30(\mathrm{~d}, J=8.6 \mathrm{~Hz}, 2 \mathrm{H}), 7.13(\mathrm{~d}, J=8.6 \mathrm{~Hz}, 2 \mathrm{H}), 3.94(\mathrm{~m}, 3 \mathrm{H})$, $1.36(\mathrm{~s}, 12 \mathrm{H})$.

2.3.3. General procedure for the preparation of $7 \mathrm{a}-\mathrm{d}$. The above boron ester $(1.2 \mathrm{mmol})$, BODIPY $6(1.0 \mathrm{mmol}), \mathrm{K}_{2} \mathrm{CO}_{3}$ solution $(2 \mathrm{M}, 6 \mathrm{~mL})$, THF $(20 \mathrm{~mL})$, toluene $(20 \mathrm{~mL})$ and $\operatorname{Pd}\left(\mathrm{PPh}_{3}\right)_{4}(100 \mathrm{mg})$ were added into a flask $(100 \mathrm{~mL})$. The 
mixture was heated under reflux overnight under $\mathrm{N}_{2}$. After evaporating the solvent under reduced pressure, water $(50 \mathrm{~mL})$ and $\mathrm{CH}_{2} \mathrm{Cl}_{2}(100 \mathrm{~mL})$ were added. The organic layer was separated and dried in $\mathrm{MgSO}_{4}$. The solvent was removed under reduced pressure. The according aldehyde derivative was obtained by column chromatography on silica gel using petroleum ether and ethyl acetate as eluent.

Compound 7a. Red solid, yield: $80 \%$. $R_{\mathrm{f}}=0.35$, (PE : EA $=$ $3:$ 1). ${ }^{1} \mathrm{H}$ NMR $\left(400 \mathrm{MHz}, \mathrm{CDCl}_{3}\right) \delta 10.14(\mathrm{~s}, 1 \mathrm{H}), 8.10(\mathrm{~d}, J=$ $7.0 \mathrm{~Hz}, 1 \mathrm{H}), 7.91(\mathrm{~s}, 1 \mathrm{H}), 7.49(\mathrm{dd}, J=16.4,8.8 \mathrm{~Hz}, 4 \mathrm{H}), 7.31(\mathrm{~s}$, $1 \mathrm{H}), 4.33(\mathrm{t}, J=6.0 \mathrm{~Hz}, 2 \mathrm{H}), 3.15(\mathrm{t}, J=1.1 \mathrm{~Hz}, 2 \mathrm{H}), 2.81(\mathrm{~s}, 3 \mathrm{H})$, $2.79(\mathrm{~s}, 3 \mathrm{H}), 2.56(\mathrm{~s}, 3 \mathrm{H}), 2.43(\mathrm{~s}, 3 \mathrm{H}), 1.91(\mathrm{~d}, J=6.3 \mathrm{~Hz}, 2 \mathrm{H})$, 1.75-1.68 (m, 2H), 1.53 (d, $J=3.9 \mathrm{~Hz}, 2 \mathrm{H}), 1.42-1.26(\mathrm{~m}, 12 \mathrm{H})$, $0.94(\mathrm{t}, J=6.0 \mathrm{~Hz}, 3 \mathrm{H}), 0.87(\mathrm{~s}, 3 \mathrm{H}) .{ }^{13} \mathrm{C} \mathrm{NMR}\left(101 \mathrm{MHz}, \mathrm{CDCl}_{3}\right)$ $\delta 186.30,160.12,155.21,148.52,140.80,139.91,127.61,126.12$, 123.06, 122.65, 122.48, 121.97, 120.42, 119.14, 108.97, 108.84, $43.29,32.50,31.83,31.61,29.41,29.22,29.06,28.82,27.37$, $22.65,22.55,15.08,14.12,14.07,12.97$. MALDI-TOF-MS, $m / z$ : calcd for $\mathrm{C}_{39} \mathrm{H}_{48} \mathrm{BF}_{2} \mathrm{~N}_{3} \mathrm{O}[\mathrm{M}]^{+}:$623.390, found: 623.393 .

Compound $7 \boldsymbol{b}$. Red solid, yield: $85 \%$. $R_{\mathrm{f}}=0.35$, (PE : EA $=$ 3 : 1). ${ }^{1} \mathrm{H}$ NMR (400 MHz, $\mathrm{CDCl}_{3}$ ) $\delta 10.15$ (s, 1H), 8.15 (dd, $J=$ 11.1, $7.9 \mathrm{~Hz}, 2 \mathrm{H}), 7.46(\mathrm{dd}, J=21.6,7.5 \mathrm{~Hz}, 2 \mathrm{H}), 7.28(\mathrm{~s}, 1 \mathrm{H})$, $7.21(\mathrm{~s}, 1 \mathrm{H}), 7.04(\mathrm{~d}, J=7.6 \mathrm{~Hz}, 1 \mathrm{H}), 4.34-4.27(\mathrm{~m}, 2 \mathrm{H}), 3.14(\mathrm{~s}$, $2 \mathrm{H}), 2.82$ (s, 3H), 2.79 (s, 3H), 2.57 (s, 3H), 2.44 (s, 3H), 1.87 (d, J $=6.6 \mathrm{~Hz}, 2 \mathrm{H}), 1.78-1.65(\mathrm{~m}, 2 \mathrm{H}), 1.52-1.54(\mathrm{~m}, 2 \mathrm{H}), 1.41-1.22$ $(\mathrm{m}, 12 \mathrm{H}), 0.95(\mathrm{t}, J=7.0 \mathrm{~Hz}, 3 \mathrm{H}), 0.84(\mathrm{~d}, J=6.6 \mathrm{~Hz}, 3 \mathrm{H}) .{ }^{13} \mathrm{C}$ NMR (101 MHz, $\left.\mathrm{CDCl}_{3}\right) \delta 186.23,155.51,148.88,140.93,140.55$, $129.80,126.06,122.53,122.48,120.91,120.48,119.18,110.29$, 108.86, 43.24, 32.50, 31.76, 29.43, 29.20, 29.12, 27.50, 22.62, $22.53,15.01,14.05,14.03,13.01$. MALDI-TOF-MS, $\mathrm{m} / \mathrm{z}$ : calcd for $\mathrm{C}_{39} \mathrm{H}_{38} \mathrm{BF}_{2} \mathrm{~N}_{3} \mathrm{O}_{2}[\mathrm{M}]^{+}:$617.300, found: 617.324.

Compound 7c. Brown solid, yield: 78\%. $R_{\mathrm{f}}=0.25$, (PE : EA $=$ $3:$ 1). ${ }^{1} \mathrm{H}$ NMR (400 MHz, $\left.\mathrm{CDCl}_{3}\right) \delta 10.14(\mathrm{~s}, 1 \mathrm{H}), 8.14$ (d, $J=$ $7.6 \mathrm{~Hz}, 1 \mathrm{H}), 7.96(\mathrm{~s}, 1 \mathrm{H}), 7.49(\mathrm{~d}, J=8.6 \mathrm{~Hz}, 2 \mathrm{H}), 7.45-7.34(\mathrm{~m}$, $3 \mathrm{H}), 7.30$ (t, $J=7.3 \mathrm{~Hz}, 1 \mathrm{H}), 7.21(\mathrm{~d}, J=8.3 \mathrm{~Hz}, 1 \mathrm{H}), 7.14(\mathrm{~d}, J=$ $8.5 \mathrm{~Hz}, 2 \mathrm{H}), 3.94(\mathrm{~s}, 3 \mathrm{H}), 3.24-3.07(\mathrm{~m}, 2 \mathrm{H}), 2.81(\mathrm{~s}, 3 \mathrm{H}), 2.79(\mathrm{~s}$, $3 \mathrm{H}), 2.57$ (s, 3H), $2.44(\mathrm{~s}, 3 \mathrm{H}), 1.80-1.67(\mathrm{~m}, 2 \mathrm{H}), 1.55-1.49(\mathrm{~m}$, 2H), $1.45-1.40(\mathrm{~m}, 2 \mathrm{H}), 0.95(\mathrm{t}, J=7.1 \mathrm{~Hz}, 3 \mathrm{H}) .{ }^{13} \mathrm{C} \mathrm{NMR}(101$ MHz, DMSO) $\delta 186.29,159.08,148.64,141.78,140.87,130.02$, $128.55,127.90,126.39,125.85,123.70,123.40,122.77,121.89$, 120.34, 120.07, 115.21, 110.01, 55.67, 32.51, 31.63, 28.84, 22.56, $15.07,14.07,13.00,12.61$. MALDI-TOF-MS, $\mathrm{m} / \mathrm{z}$ : calcd for $\mathrm{C}_{39} \mathrm{H}_{48} \mathrm{BF}_{2} \mathrm{~N}_{3} \mathrm{O}[\mathrm{M}]^{+}:$623.390, found: 623.409 .

Compound $7 \boldsymbol{d}$. Brown solid, yield: $82 \% . R_{\mathrm{f}}=0.25$, (PE : EA = $3: 1) .{ }^{1} \mathrm{H} \mathrm{NMR}\left(400 \mathrm{MHz}, \mathrm{CDCl}_{3}\right) \delta 10.13(\mathrm{~s}, 1 \mathrm{H}), 8.20(\mathrm{~d}, J=$ $7.9 \mathrm{~Hz}, 2 \mathrm{H}), 7.45$ (dd, $J=12.6,8.3 \mathrm{~Hz}, 3 \mathrm{H}), 7.38-7.28(\mathrm{~m}, 2 \mathrm{H})$, 7.15-7.08 (m, 4H), $3.91(\mathrm{~s}, 3 \mathrm{H}), 3.11(\mathrm{~d}, J=5.6 \mathrm{~Hz}, 2 \mathrm{H}), 2.80(\mathrm{~s}$, $3 \mathrm{H}), 2.77(\mathrm{~s}, 3 \mathrm{H}), 2.52(\mathrm{~s}, 3 \mathrm{H}), 2.39(\mathrm{~s}, 3 \mathrm{H}), 1.77-1.61(\mathrm{~m}, 2 \mathrm{H})$, 1.53-1.48 (m, 2H), $1.40(\mathrm{dd}, J=14.3,7.1 \mathrm{~Hz}, 2 \mathrm{H}), 0.93(\mathrm{t}, J=$ $7.1 \mathrm{~Hz}, 3 \mathrm{H}) .{ }^{13} \mathrm{C}$ NMR (101 MHz, DMSO) $\delta 186.26,159.06$, $155.48,148.87,141.86,141.48,130.15,129.97,128.50,126.33$, 122.76, 121.83, 120.39, 120.08, 115.26, 111.21, 109.90, 55.64, 32.49 , 31.56, 28.81, 22.53, 15.00, 14.06, 13.00, 12.65. MALDITOF-MS, $m / z$ : calcd for $\mathrm{C}_{39} \mathrm{H}_{38} \mathrm{BF}_{2} \mathrm{~N}_{3} \mathrm{O}_{2}[\mathrm{M}]^{+}:$617.300, found: 617.305 .

2.3.4. General procedure for preparation of CB1-4. The aldehyde derivative $(0.20 \mathrm{mmol})$, dissolved in $\mathrm{CHCl}_{3}(20 \mathrm{~mL})$ and $\mathrm{CH}_{3} \mathrm{CN}(20 \mathrm{~mL})$, was condensed with 2-cyanoacetic acid $(0.40 \mathrm{mmol})$ in the presence of piperidine $(0.05 \mathrm{~mL})$. The mixture was heated under reflux for $24 \mathrm{~h}$ with a nitrogen atmosphere. After cooling to room temperature, the mixture was poured to $\mathrm{CH}_{2} \mathrm{Cl}_{2}(100 \mathrm{~mL})$ and washed with water $(3 \times 50$ $\mathrm{mL}$ ). Organic layer was dried over $\mathrm{MgSO}_{4}$ and solvent was evaporated and the residue was purified by silica gel column chromatography using $\mathrm{CH}_{2} \mathrm{Cl}_{2}$ and $\mathrm{CH}_{3} \mathrm{OH}$ as eluent.

Dye CB1. Dark red solid, yield: $78 \% . R_{\mathrm{f}}=0.56,\left(\mathrm{CH}_{2} \mathrm{Cl}_{2}-\right.$ $\left.: \mathrm{CH}_{3} \mathrm{OH}=10: 1\right) .{ }^{1} \mathrm{H}$ NMR (600 MHz, DMSO) $\delta 8.19(\mathrm{~d}, J=$ $7.5 \mathrm{~Hz}, 1 \mathrm{H}), 8.12(\mathrm{~s}, 1 \mathrm{H}), 7.86(\mathrm{~s}, 1 \mathrm{H}), 7.67(\mathrm{~d}, J=7.7 \mathrm{~Hz}, 1 \mathrm{H})$, $7.61(\mathrm{~d}, J=8.1 \mathrm{~Hz}, 1 \mathrm{H}), 7.46(\mathrm{t}, J=7.6 \mathrm{~Hz}, 1 \mathrm{H}), 7.36(\mathrm{~d}, J=$ $8.2 \mathrm{~Hz}, 1 \mathrm{H}), 7.19(\mathrm{t}, J=7.3 \mathrm{~Hz}, 1 \mathrm{H}), 4.40(\mathrm{~s}, 2 \mathrm{H}), 3.18-3.06(\mathrm{~m}$, $2 \mathrm{H}), 2.46(\mathrm{~s}, 3 \mathrm{H}), 2.45(\mathrm{~s}, 3 \mathrm{H}), 2.42(\mathrm{~s}, 3 \mathrm{H}), 2.40(\mathrm{~s}, 3 \mathrm{H}), 1.78(\mathrm{~d}, J$ $=5.7 \mathrm{~Hz}, 2 \mathrm{H}), 1.69-1.62(\mathrm{~m}, 2 \mathrm{H}), 1.50-1.46(\mathrm{~m}, 2 \mathrm{H}), 1.39-1.35$ $(\mathrm{m}, 2 \mathrm{H}), 1.32(\mathrm{~d}, J=7.0 \mathrm{~Hz}, 2 \mathrm{H}), 1.20(\mathrm{dd}, J=14.4,7.5 \mathrm{~Hz}, 8 \mathrm{H})$, 0.89 (t, $J=7.2 \mathrm{~Hz}, 3 \mathrm{H}), 0.80$ (d, $J=7.0 \mathrm{~Hz}, 3 \mathrm{H}) .{ }^{13} \mathrm{C}$ NMR (151 MHz, DMSO) $\delta 155.70,150.65,148.15,140.65,139.73,138.37$, $137.21,130.93,130.11,129.03,128.71,128.24,126.42,125.79$, $123.10,122.77,122.64,122.43,121.08,119.29,118.74,113.72$, 112.59, 109.83, 109.77, 109.49, 56.47, 33.02, 32.34, 31.62, 29.20, 29.18, 29.09, 29.03, 27.01, 22.49, 22.31, 15.36, 14.84, 14.43, 14.38, 13.73, 13.20. MALDI-TOF-MS, $\mathrm{m} / \mathrm{z}$ : calcd for $\mathrm{C}_{42} \mathrm{H}_{49} \mathrm{BF}_{2} \mathrm{~N}_{4} \mathrm{O}_{2}[\mathrm{M}]^{+}$: 690.390; found: 690.389 .

Dye CB2. Dark red solid, yield: $82 \% . R_{\mathrm{f}}=0.55,\left(\mathrm{CH}_{2} \mathrm{Cl}_{2}-\right.$ $\left.: \mathrm{CH}_{3} \mathrm{OH}=10: 1\right) .{ }^{1} \mathrm{H}$ NMR (600 MHz, DMSO) $\delta 8.20(\mathrm{~d}, J=$ $6.5 \mathrm{~Hz}, 1 \mathrm{H}), 8.17$ (d, $J=6.8 \mathrm{~Hz}, 1 \mathrm{H}), 7.91(\mathrm{~s}, 1 \mathrm{H}), 7.60-7.55(\mathrm{~m}$, $2 \mathrm{H}), 7.46(\mathrm{t}, J=7.3 \mathrm{~Hz}, 1 \mathrm{H}), 7.21(\mathrm{t}, J=7.1 \mathrm{~Hz}, 1 \mathrm{H}), 7.09(\mathrm{~d}, J=$ $6.7 \mathrm{~Hz}, 1 \mathrm{H}), 4.41(\mathrm{~s}, 2 \mathrm{H}), 3.09(\mathrm{~s}, 2 \mathrm{H}), 2.48(\mathrm{~s}, 6 \mathrm{H}), 2.41(\mathrm{~s}, 6 \mathrm{H})$, $1.76(\mathrm{~s}, 2 \mathrm{H}), 1.65(\mathrm{~s}, 2 \mathrm{H}), 1.48(\mathrm{~s}, 2 \mathrm{H}), 1.37(\mathrm{~d}, J=6.6 \mathrm{~Hz}, 2 \mathrm{H})$, $1.23-1.13(\mathrm{~m}, 10 \mathrm{H}), 0.90(\mathrm{t}, J=6.8 \mathrm{~Hz}, 3 \mathrm{H}), 0.78(\mathrm{~m}, J=6.6 \mathrm{~Hz}$, $3 \mathrm{H}) .{ }^{13} \mathrm{C}$ NMR (151 MHz, DMSO) $\delta$ 155.41, 151.10, 148.38, $140.81,140.66,139.06,137.58,135.96,132.25,131.06,130.20$, $126.32,126.03,122.34,121.75,121.27,120.83,120.72,119.31$, $111.52,109.77,51.60,32.81,32.35,31.57,29.26,29.23,29.11$, 29.08, 27.05, 22.50, 22.29, 15.40, 14.77, 14.35, 14.32, 13.92, 13.13. MALDI-TOF-MS, $m / z$ : calcd for $\mathrm{C}_{41} \mathrm{H}_{39} \mathrm{BF}_{2} \mathrm{~N}_{4} \mathrm{O}_{3}[\mathrm{M}]^{+}$: 684.310, found: 684.334 .

Dye CB3. Dark solid, yield: $77 \% . R_{\mathrm{f}}=0.52,\left(\mathrm{CH}_{2} \mathrm{Cl}_{2}: \mathrm{CH}_{3} \mathrm{OH}\right.$ $=10: 1) .{ }^{1} \mathrm{H}$ NMR (600 MHz, DMSO) $\delta 8.31(\mathrm{~d}, J=7.7 \mathrm{~Hz}, 1 \mathrm{H})$, $8.24(\mathrm{~s}, 1 \mathrm{H}), 7.79(\mathrm{~s}, 1 \mathrm{H}), 7.59(\mathrm{~d}, J=8.7 \mathrm{~Hz}, 2 \mathrm{H}), 7.46(\mathrm{t}, J=$ $7.7 \mathrm{~Hz}, 1 \mathrm{H}), 7.37$ (q, $=8.3 \mathrm{~Hz}, 2 \mathrm{H}), 7.34-7.29(\mathrm{~m}, 2 \mathrm{H}), 7.25$ (d, $J$ $=8.8 \mathrm{~Hz}, 2 \mathrm{H}), 3.90(\mathrm{~s}, 3 \mathrm{H}), 3.14(\mathrm{~s}, 1 \mathrm{H}), 2.47(\mathrm{~s}, 3 \mathrm{H}), 2.46(\mathrm{~s}, 3 \mathrm{H})$, $2.44(\mathrm{~s}, 3 \mathrm{H}), 2.43(\mathrm{~s}, 3 \mathrm{H}), 1.72-1.66(\mathrm{~m}, 2 \mathrm{H}), 1.55-1.49(\mathrm{~m}, 2 \mathrm{H})$, $1.40(\mathrm{dd}, J=14.7,7.3 \mathrm{~Hz}, 2 \mathrm{H}), 0.92(\mathrm{t}, J=7.3 \mathrm{~Hz}, 3 \mathrm{H}) .{ }^{13} \mathrm{C} \mathrm{NMR}$ (151 MHz, DMSO) $\delta 166.51,162.78,159.11,155.30,148.24$, 141.46, 140.37, 138.98, 137.39, 132.10, 130.16, 129.70, 128.78, 126.94, 126.30, 124.39, 123.24, 122.87, 120.41, 119.93, 119.53, $115.83,112.56,110.11,110.03,109.82,109.31,55.97,33.00$, $32.37,31.56,22.33,15.38,14.82,14.43,14.39,13.19$. MALDITOF-MS, $m / z$ : calcd for $\mathrm{C}_{42} \mathrm{H}_{49} \mathrm{BF}_{2} \mathrm{~N}_{4} \mathrm{O}_{2}[\mathrm{M}]^{+}$: 690.390; found: 690.365 .

Dye CB4. Dark solid, yield: $79 \% . R_{\mathrm{f}}=0.50,\left(\mathrm{CH}_{2} \mathrm{Cl}_{2} / \mathrm{CH}_{3} \mathrm{OH}=\right.$ 10 : 1). ${ }^{1} \mathrm{H}$ NMR (600 MHz, DMSO) $\delta 8.35(\mathrm{~d}, J=7.9 \mathrm{~Hz}, 1 \mathrm{H}), 8.30$ $(\mathrm{d}, J=7.6 \mathrm{~Hz}, 1 \mathrm{H}), 7.77(\mathrm{~s}, 1 \mathrm{H}), 7.57(\mathrm{~d}, J=8.8 \mathrm{~Hz}, 2 \mathrm{H}), 7.46(\mathrm{t}, J$ $=7.7 \mathrm{~Hz}, 1 \mathrm{H}), 7.32(\mathrm{dd}, J=16.0,7.9 \mathrm{~Hz}, 2 \mathrm{H}), 7.22(\mathrm{~d}, J=8.7 \mathrm{~Hz}$, $3 \mathrm{H}), 7.15$ (s, 1H), 3.87 (s, 3H), 3.10 (s, 1H), 2.44 (s, 3H), 2.41 (s, 
6H), 2.38 (s, 3H), 1.65 (s, 2H), 1.47 (d, $J=7.6 \mathrm{~Hz}, 2 \mathrm{H}), 1.38$ (dd, $J$ $=14.7,7.3 \mathrm{~Hz}, 2 \mathrm{H}), 0.90(\mathrm{t}, J=7.3 \mathrm{~Hz}, 3 \mathrm{H}) .{ }^{13} \mathrm{C} \mathrm{NMR}(151 \mathrm{MHz}$, DMSO) $\delta 162.63,160.84,159.03,156.18,151.35,148.58,141.52$, $141.13,137.77,135.55,130.84,129.97,129.60,128.68,126.90$, $122.73,122.53,122.30,121.12,120.50,115.87,111.45,110.10$, 55.92, 32.34, 31.41, 29.50, 22.28, 15.46, 14.77, 14.37, 14.26, 13.89. MALDI-TOF-MS, $m / z$ : calcd for $\mathrm{C}_{41} \mathrm{H}_{39} \mathrm{BF}_{2} \mathrm{~N}_{4} \mathrm{O}_{3}[\mathrm{M}]^{+}$: 684.310; found: 684.325 .

\section{Results and discussion}

\subsection{Synthesis and characterization}

The synthetic strategy employed to access the target compounds CB1-4 is shown in Scheme 1. Compounds 2a-d were prepared from $N$-substituted carbazoles with NBS, according to the similar published procedure. ${ }^{41}$ Afterward, the Miyaura borylation reaction of the compound $\mathbf{2 a - d}$ and commercially available bis(pinacolato)diboron was carried out using KOAc as a base and $\mathrm{Pd}\left(\mathrm{PPh}_{3}\right)_{2} \mathrm{Cl}_{2}$ as the catalyst in toluene, resulting in corresponding donor motif 3a-d. ${ }^{42}$ The key intermediates, 2iodo-6-formyl BODIPY 6, was prepared from 2,4-dimethylpyrrole, through a three steps conversion, including condensation-acylation-halogenation reaction sequence. In the next step, palladium-catalyzed Suzuki coupling of $\mathbf{3 a - d}$ with iodo conjugated bridge 6 produce the corresponding aldehydes 7a-d in excellent yields, respectively. At last, the synthesis of target dyes CB1-4 were achieved by the Knoevenagel condensation of the corresponding $7 \mathbf{a}-\mathbf{d}$ with cyanoacetic acid in the presence of a catalytic amount of piperidine. These target molecules were sufficiently soluble in toluene, $\mathrm{CH}_{2} \mathrm{Cl}_{2}, \mathrm{CHCl}_{3}$ and THF to permit their characterization in solution as well as their application in DSSCs devices. The structural assignments of these dyes were confirmed by a range of spectroscopic techniques, including NMR and MALDI-TOF-MS.

\subsection{Photophysical properties}

The UV-vis absorption spectra of CB1-4 recorded in a diluted solution of $\mathrm{CHCl}_{3}\left(1 \times 10^{-5} \mathrm{M}\right)$ at room temperature are shown in Fig. 1. For comparison, the reference BODIPY 4 without substitutions at 2,6-position was also tested in the same conditions. The corresponding data of the measurements are listed in Table 1. As shown in Fig. 1. All these dyes CB1-4 exhibit broad absorption spectra with two distinct absorption bands: one in the range of $280-400 \mathrm{~nm}$, the other in the range of 420 $650 \mathrm{~nm}$. The band in the high-energy region are attributed to interplay of lower-intensity BODIPY-based $\mathrm{S}_{0} \rightarrow \mathrm{S}_{2}$ and carbazole-based $\pi-\pi^{*}$ transitions. The highly intense absorption band in the low-energy region are partly characteristics of the $\pi-\pi^{*}\left(\mathrm{~S}_{0} \rightarrow \mathrm{S}_{1}\right)$ transition of the BODIPY moiety. In addition, CB1-4 show obviously broader and red-shift absorption profile as compared to the reference BODIPY 4, suggesting that there is an intense intermolecular charge transfer (ICT) transition in these $\mathrm{D}-\pi-\mathrm{A}$ molecules. ${ }^{43}$ Consequently, the low-energy absorption region are originated from the mixture of $\pi-\pi^{*}\left(\mathrm{~S}_{0}\right.$ $\rightarrow S_{1}$ ) transition of BODIPY moiety and the ICT transitions between the carbazole donor and cyanoacetic acid acceptor. In

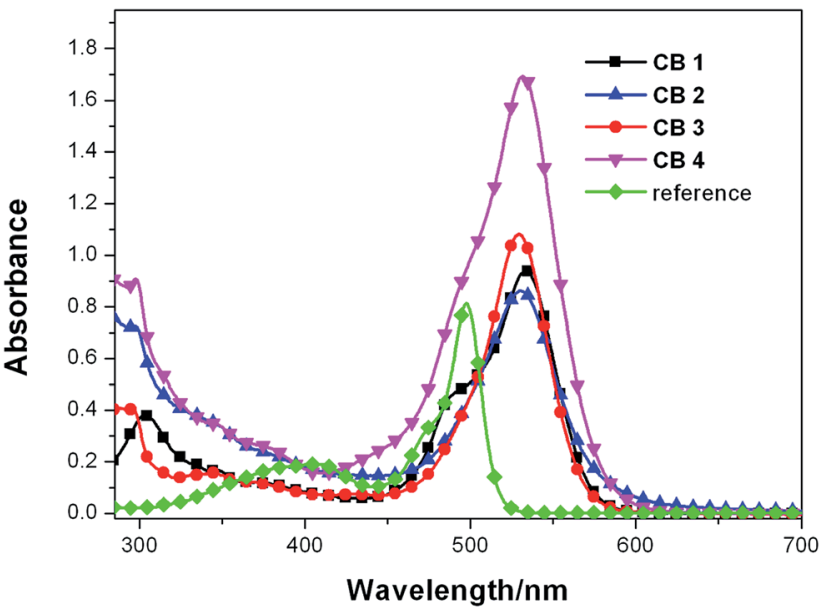

Fig. 1 Absorption spectra of dyes CB1-4 in $\mathrm{CHCl}_{3}\left(1 \times 10^{-5} \mathrm{M}\right)$.

comparision with the unmodified BODIPY 4, the absorption maxima of CB1, CB2, CB3 and CB4 is bathochromic shifted by about $32 \mathrm{~nm}$, indicating that 2,6-modificated with donor and acceptor units, respectively, efficient extended the conjugation length of these dyes, leading to the reduced gap between the highest occupied molecular orbital (HOMO) and lowest unoccupied molecular orbital (LUMO) levels. In comparision with CB1 and CB3, CB2 and CB4 exhibit broader absorption pattern with the low energy edge of absorption bands red-shift about $20 \mathrm{~nm}$ (Table 1), which is due to the factor that the $N$-methoxyphenyl carbazole is a more electron-rich donor relative to the $\mathrm{N}$-octyl carbazole counterpart, thus resulting in much intensive ICT transitions. In the other hand, the molar extinction coefficients $(\varepsilon)$ of the maximum absorption bands of 4, CB1, CB2, CB3 and CB4 were $0.81 \times 10^{5}, 0.95 \times 10^{5}, 0.87 \times 10^{5}, 1.09 \times 10^{5}$ and $1.71 \times 10^{5} \mathrm{M}^{-1} \mathrm{~cm}^{-1}$, respectively, which are higher than the well-known dye N719 $\left(1.42 \times 10^{4} \mathrm{M}^{-1} \mathrm{~cm}^{-1}\right) \cdot{ }^{44}$ Due to the extended conjugation length, CB1-4 display higher $\varepsilon$ values than BODIPY 4. Furthermore, in comparison with CB1 and CB2, dyes CB3 and CB4 exhibit stronger absorption ability with higher $\varepsilon$ values, indicating that carbazole unit bonding to BODIPY module with 2-position is advantageous to form effective conjugation than that with 3-position. Generally, it is believed that a strong absorption in a broad visible region is favorable for photocurrent generation in DSSCs. ${ }^{45}$

CB1-4 were self-adsorbed on $\mathrm{TiO}_{2}$ nanostructured film by an electrode soaking in dry $\mathrm{CH}_{2} \mathrm{Cl}_{2}$ solution. In general, when sensitizers are anchored onto a nanocrystalline $\mathrm{TiO}_{2}$ surface, the deprotonation and aggregation of the dye molecules would affect on the UV-vis absorption profiles. Deprotonation and $\mathrm{H}$ aggregation always result in blue-shifted of absorption, while J-aggregates mainly lead to the red-shifted absorption. ${ }^{46}$ As shown in Fig. 2 , the $\lambda_{\max }$ of CB1, CB2, CB3 and CB4 were blueshifted by $35 \mathrm{~nm}, 27 \mathrm{~nm}, 30 \mathrm{~nm}$ and $19 \mathrm{~nm}$ as compared to those in solution. This is ascribed to deprotonation of the dyes and/or the formation of $\mathrm{H}$-aggregation on the semiconductor surface. CB2 and CB4 have much less blue-shift in comparison with CB1 and CB3, indicating that CB2 and CB4 with $N$ methoxyphenyl carbazole donor motif enable better dispersion 
Table 1 Photophysical and electrochemical characteristics for sensitizers

\begin{tabular}{llllll}
\hline Dye & $\lambda_{\max }{ }^{a}(\mathrm{~nm}) / \varepsilon\left(\times 10^{5} \mathrm{M}^{-1} \mathrm{~cm}^{-1}\right)$ & $\lambda_{\max }{ }^{b}(\mathrm{~nm})$ & $E_{\text {ox }}{ }^{c}(\mathrm{~V}) v s . \mathrm{NHE}$ & $E_{0,0}{ }^{d}(\mathrm{eV}) / \lambda_{\text {onset }}(\mathrm{nm})$ & $2.05 / 603$ \\
\hline CB1 & $531 / 0.95$ & 496 & 1.07 & $2.00 / 620$ & -0.98 \\
CB2 & $529 / 0.87$ & 502 & 0.99 & $2.04 / 605$ & -1.01 \\
CB3 & $530 / 1.09$ & 500 & 1.05 & $1.92 / 646$
\end{tabular}

${ }^{a}$ In $\mathrm{CHCl}_{3}$ solutions. ${ }^{b}$ Absorption maximum on $\mathrm{TiO}_{2}$ was obtained through measuring the dyes adsorbed on $3 \mu \mathrm{m}$ TiO ${ }_{2}$ nanoparticle films in a $\mathrm{CHCl}_{3}$ solution. ${ }^{c} E_{\mathrm{ox}}$ was measured in $\mathrm{CH}_{2} \mathrm{Cl}_{2}$ and calibrated with ferrocene as an external reference. ${ }^{d} E_{0,0}$ was estimated from the absorption thresholds from absorption spectra of dyes adsorbed on the $\mathrm{TiO}_{2}$ film, $E_{0,0}=1240 / \lambda_{\text {onset. }}{ }^{e}$ Computed from the formula $E_{\mathrm{ox}}^{*}=E_{\mathrm{ox}}-E_{0,0}$.

and capable of better photovoltaic performance. On the other hand, the spectra of dyes adsorbed on $\mathrm{TiO}_{2}$ surface show broader absorption bands and each with an obvious shoulder band $(\sim 550 \mathrm{~nm})$ as contrast to those in $\mathrm{CH}_{2} \mathrm{Cl}_{2}$ solution, this may be attributed to strong intermolecular interactions, such as dipolar intermolecular interactions and nonbonding intermolecular interactions (e.g. $-\mathrm{F} \cdots \mathrm{N}-)$, between the individual molecules in the solid state.

\subsection{Electrochemical properties}

Energy levels of sensitizers are crucial to judge the possibilities of electron injection from the excited dyes to the conductor band of $\mathrm{TiO}_{2}$ and dyes regeneration by the iodide/triiodide electrolyte. The electrochemical properties of these sensitizers were measured using cyclic voltammetry (CV) in $\mathrm{CH}_{2} \mathrm{Cl}_{2}$ solution containing $0.1 \mathrm{M} \mathrm{TBAPF}_{6}$ as supporting electrolyte. The CV curves of CB1-4 are depicted in Fig. 3 and the results are summarized in Table 1 . The electrochemical study reveals that all the novel dyes are reversibly oxidized, consistent with the formation of stable radical-cations, which is a key requirement for efficient electronic processes in DSSCs. CB1-4 exhibit two oxidation and two reduction waves corresponding to the formation of dication and dianion radicals respectively. As shown in Fig. 3, CB1-4 present differential first onset oxidation potential as $1.07,0.99,1.05$ and $0.97 \mathrm{~V}$, respectively, indicating

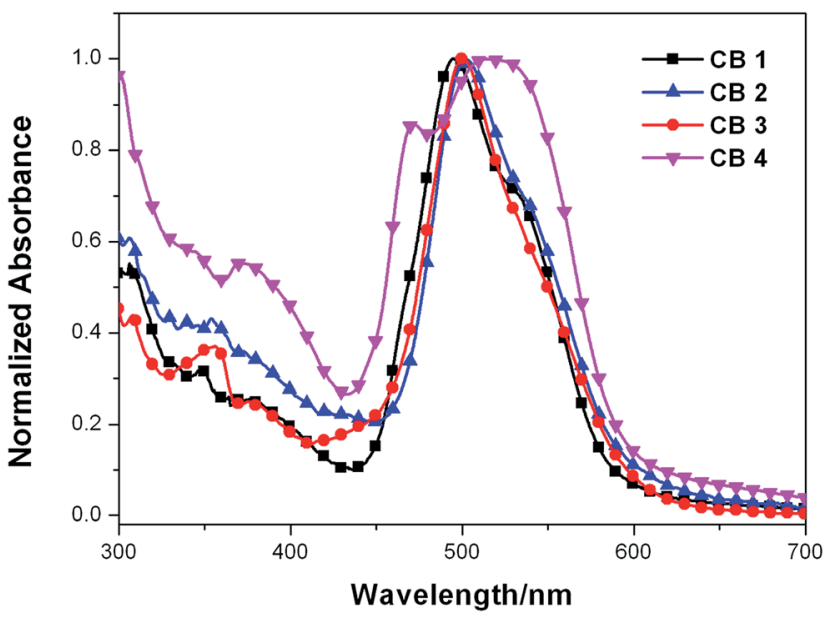

Fig. 2 Normalized absorption spectra of dyes CB1-4 anchoring on the $3 \mu \mathrm{m}$ porous $\mathrm{TiO}_{2}$ nanoparticle film. the carbazole donor variety and their connect manner have significant affects on the $E_{\text {ox }}$. In comparision with CB1 (1.07 V), the oxidation of $\mathbf{C B 2}(0.99 \mathrm{~V})$ shifted to the lower oxidation potentials, which is due to the factor that the electron-rich methoxyphenyl could strengthen the electron donating ability of carbazole. Similar phenomenon was observed in CB3 and CB4. In addition, the substitutional position of the electron donor group also affects on the oxidation potential of the dyes. Both 2-position carbazole substituted CB3 (1.05 V) and CB4 $(0.97 \mathrm{~V})$ are oxidized at a slightly lower potential than
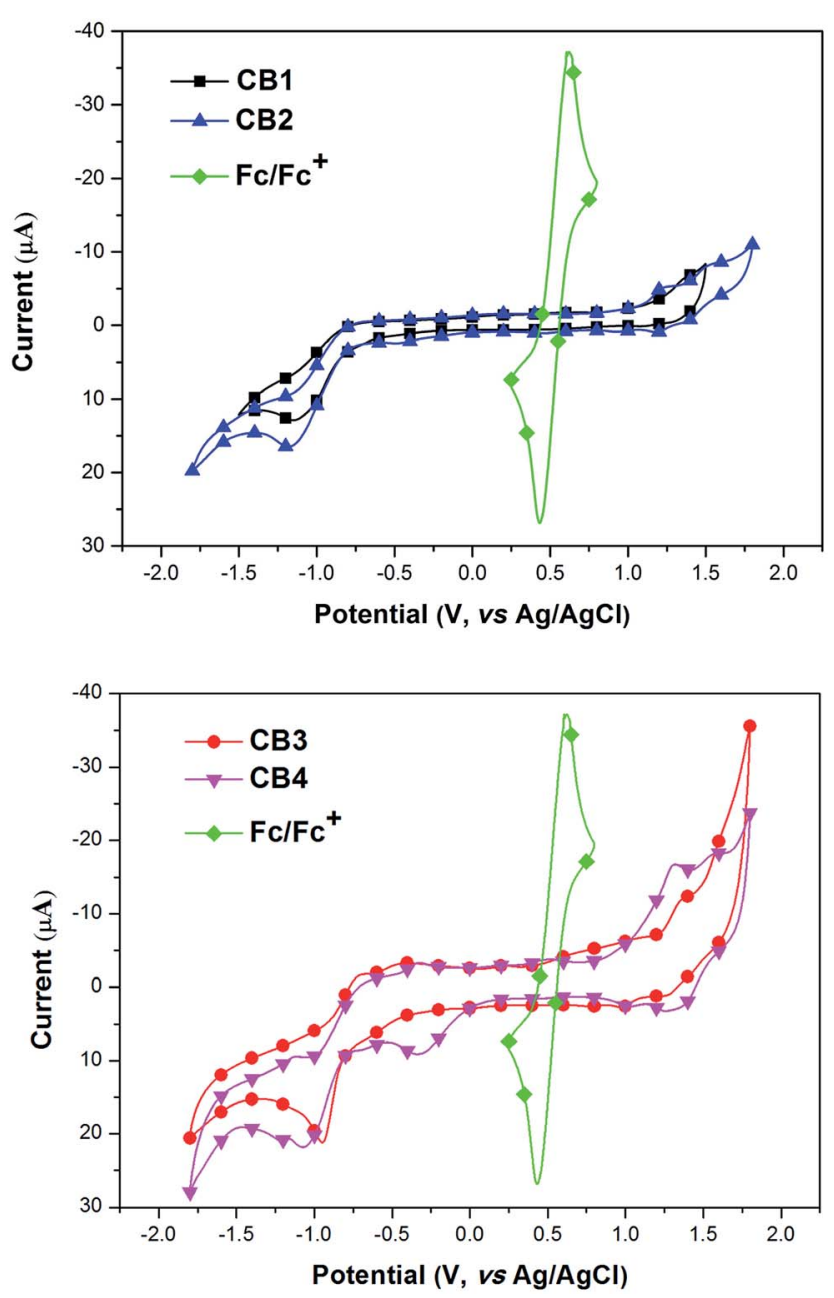

Fig. 3 Cyclic voltammograms of dyes $\mathrm{CB1}-4$ measured in $\mathrm{CH}_{2} \mathrm{Cl}_{2}$. 


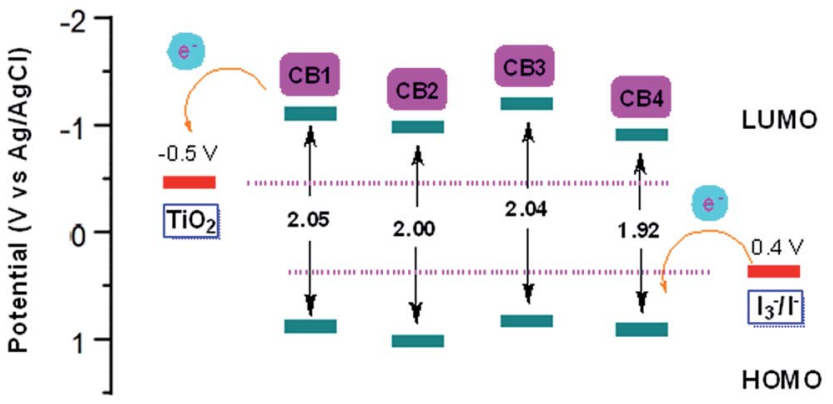

Fig. 4 Schematic energy levels of dyes CB1-4 (figure adapted from ref. 33).

corresponding 3-position carbazole substituted analogs, CB1 and CB2, due to single electronegative nitrogen atom of carbazole are closer to the electron acceptor unit in the former ones. All the four potential $E_{\text {ox }}$ values are substantially more positive about $0.59 \mathrm{~V}$ than $\mathrm{I}^{-} / \mathrm{I}_{3}{ }^{-}$redox couples $(0.40 \mathrm{~V} v s$. NHE), indicating that driving forces for the dye regeneration to efficiently compete with the recapture of injected electrons by the dye cation are sufficient (Fig. 4). ${ }^{47}$ The zero-zero transition energy values $\left(E_{0,0}\right)$, which are related to the band gap energy $\left(E_{\mathrm{g}}\right)$, were estimated from the onset wavelength of the absorption spectrum in $\mathrm{CHCl}_{3}$ solution. The excited-state oxidation potentials $\left(E_{\text {ox }}^{*}\right)$ reflect the lowest unoccupied molecular orbital (LUMO) levels of dyes. It can be calculated from subtraction between $E_{\mathrm{ox}}$ and $E_{0,0}\left(E_{\mathrm{ox}}^{*}=E_{\mathrm{Ox}}-E_{0,0}\right)$, were $-0.98 \mathrm{~V}$ for $\mathbf{C B 1},-1.01 \mathrm{~V}$ for CB2, $-0.99 \mathrm{~V}$ for CB3 and $-0.95 \mathrm{~V}$ for CB4, which are all more negative than the conduction band $\left(E_{\mathrm{cb}}\right)$ of the $\mathrm{TiO}_{2}$ electrode $(-0.50 \mathrm{~V})$, suggesting a sufficient driving force for the electron injection. ${ }^{48}$ On the basis of the $E_{\mathrm{ox}}$ and $E_{\mathrm{ox}}^{*}$ energy values, these new carbazole-BODIPY based dyes are considered to have proper electronic energy levels as a promising sensitizer in DSSCs.

\subsection{Density functional theory calculations}

For a better understanding of the structural and electronic features of these novel dyes CB1-4, the TD-DFT theoretical calculations were further performed, and the optimized structures and the electronic distribution in HOMO and LUMO levels are presented in Fig. 5. All calculations were carried out with the Gaussian 09 program suite by using the B3LYP method and 6-31 $\mathrm{G}^{*}$ basis set. ${ }^{49}$ From the optimized ground-state geometries of the dyes in Fig. 5, it found that the dihedral angle between the carbazole unit and the BODIPY framework are computed to be $61.8^{\circ}$ for $\mathbf{C B 1}, 52.3^{\circ}$ for $\mathbf{C B 2}, 60.4^{\circ}$ for $\mathbf{C B 3}$, and $50.0^{\circ}$ for CB4, respectively, indicating that all these dyes exhibit relatively nonplanar molecule structures, which may not only suppress the aggregation but also increase the molar extinction coefficient of the organic dyes $\left(10^{5} \mathrm{M}^{-1} \mathrm{~cm}^{-1}\right) .{ }^{50}$ Obviously, CB2 and CB4, with $N$-methoxyphenyl carbazole as electron donating unit, display more coplanar $\pi$-conjugate backbone compared to CB1 and CB3. Moreover, CB3 and CB4, with carbazole unit linked to BODIPY at 2-position, show slightly more coplanar $\pi$ conjugate backbone relative to the 3-position linked counterparts, CB1 and CB2. Generally, the high degree of molecular coplanarity could facilitate efficient ICT transition in the D- $\pi-\mathrm{A}$ structural molecule and result in red-shifted absorption, which is consistent with the UV-vis absorption spectra observed in solution.

The electron distributions of CB1-4 indicate that $\pi$-electrons in the HOMO are distributed along the carbazole unit, while their LUMO orbitals are mainly localized on cyanoacrylic acid

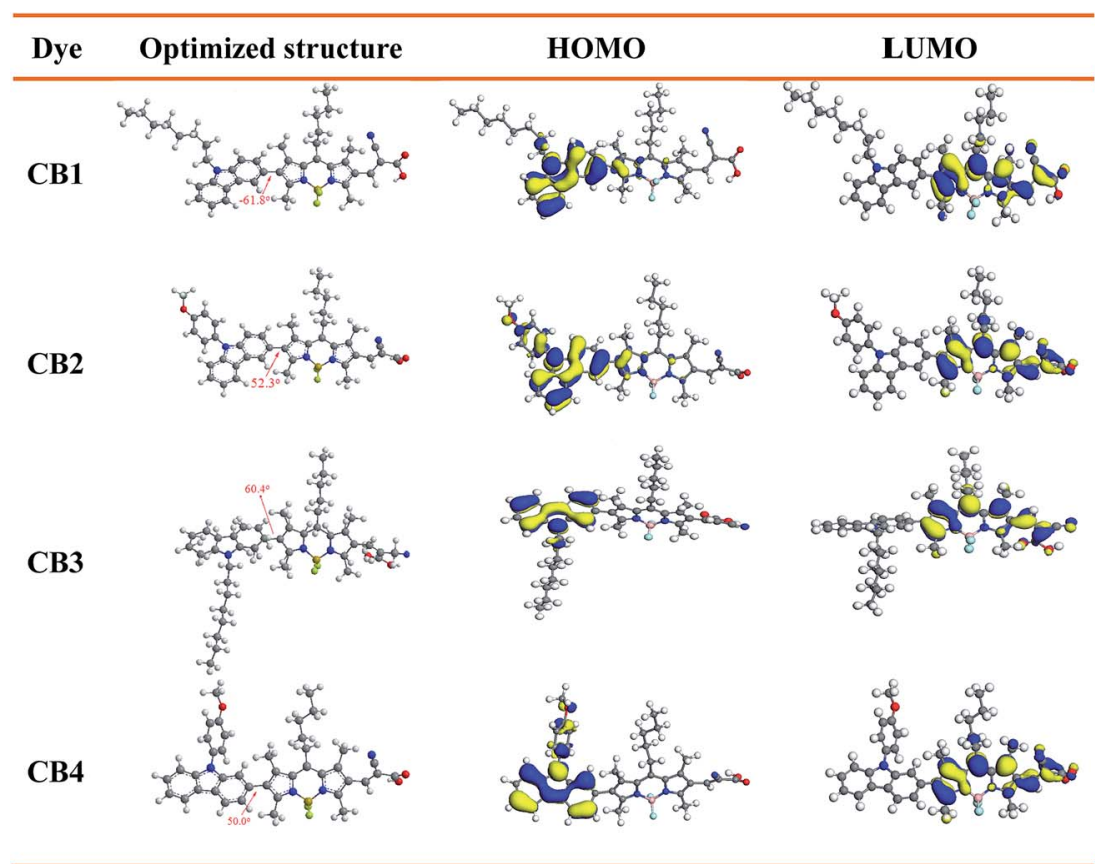

Fig. 5 Optimized structures and electron distribution in HOMO and LUMO levels of CB1-4. 


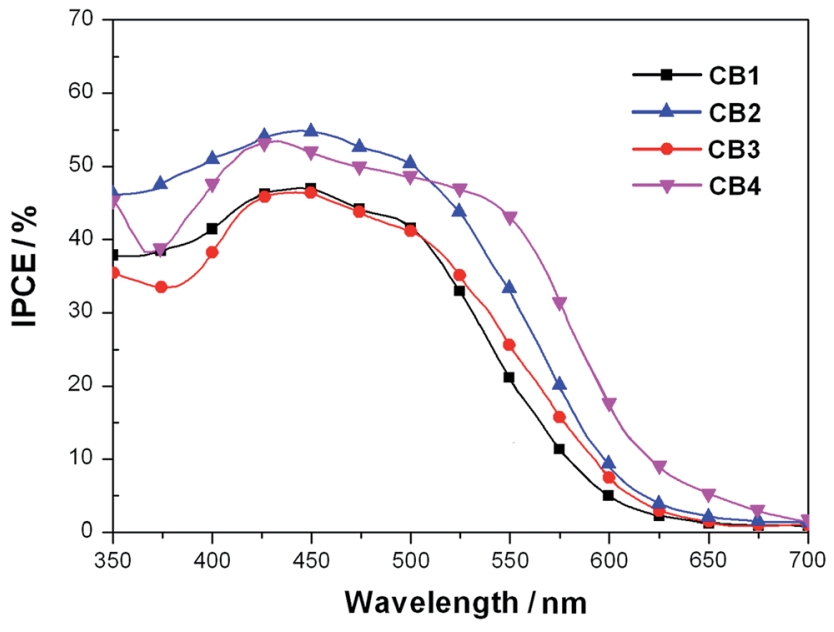

Fig. 6 IPCE spectra of DSSCs based on CB1-4.

and its adjacent BODIPY motifs (Fig. 5). The result suggests that the HOMO $\rightarrow$ LUMO excitation by light would induce a transfer of the electron from electron-donating carbazole moiety to electron-accepting BODIPY-cyanoacrylic acid moiety. These electron distributions allow sufficient charge separation within the dyes. Apparently, the electron transfer from the HOMO to the LUMO can easily result in electron redistribution from the carbazole unit to the cyanoacrylic acid moiety, which is highly significant in the electron injection from excited state dyes into the $\mathrm{CB}$ band of $\mathrm{TiO}_{2}$ semiconductor. Since $N$-methoxyphenyl carbazole unit possess stronger electron-donating ability than that of $N$-octyl carbazole unit, dyes CB2 and CB4 with better molecular coplanarity deservedly present more intense movement of electrons, which in turn lead to more efficient injection of electrons into the $\mathrm{TiO}_{2}$ photoelectrode.

\subsection{Photovoltaic performance}

In order to investigate the photovoltaic performance of CB1-4, a set of DSSCs were fabricated and tested under the standard

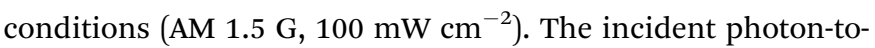
current efficiency (IPCE) and photocurrent density-photovoltage $(J-V)$ curves of cells based on these dyes were measured, and the results are depicted in Fig. 6 and 7, respectively, and the corresponding data are summarized in Table 2. The photovoltaic performance of these dyes as sensitizers for DSSCs was tested using $0.5 \mathrm{M}$ LiI $0.05 \mathrm{M} \mathrm{I}_{2}, 0.1 \mathrm{M}$ guanidinium thiocyanate, 0.6 M PMII and 0.5 M 4-tert-butylpyridine (TBP) in 3-methoxypropionitrile as the redox electrolyte. As well known, the thickness of the $\mathrm{TiO}_{2}$ film is one of the important factors to dominantly affect the performance of a cell. Generally, thicker $\mathrm{TiO}_{2}$ films can provide more dye molecules to adsorb on them. ${ }^{51}$ Meanwhile, the electron transporting path becomes longer with thicker $\mathrm{TiO}_{2}$ films, which may cause a higher probability of recombination. As a result, the open-circuit voltage $\left(V_{\text {oc }}\right)$ for the pertinent DSSCs may decrease with further increase in the thickness of the $\mathrm{TiO}_{2}$ film. ${ }^{.2}$ The optimized thickness of $200 \mathrm{~nm}$ particle sized $\mathrm{TiO}_{2}$ film for the referenced N719 dye in our work is about $3 \mu \mathrm{m}$. In order to make a comparison, the four

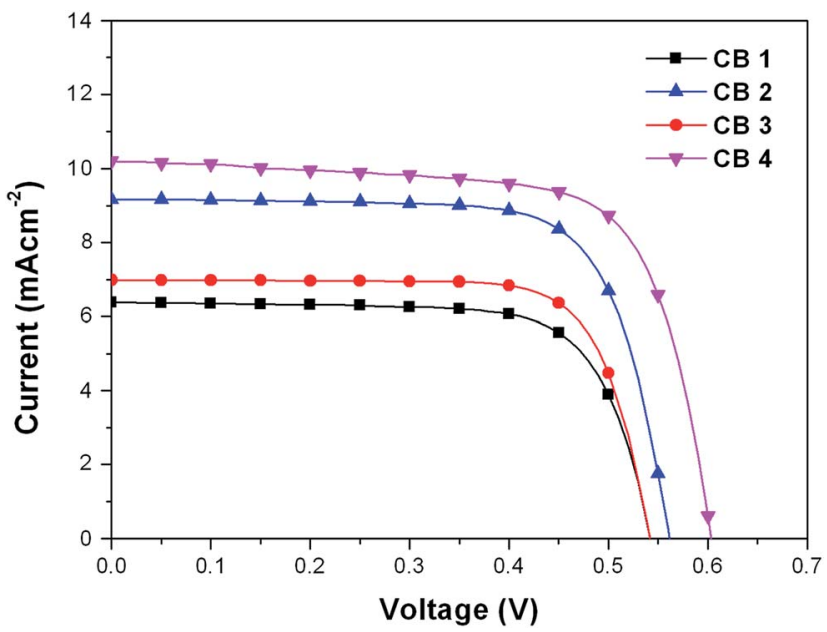

Fig. 7 J-V characteristics observed for the DSSCs fabricated by CB14.

sensitizers (CB1-4) are also adopted the same thickness of the $\mathrm{TiO}_{2}$ film.

The IPCE spectra of CB1, CB2, CB3 and CB4 for DSSCs are plotted as a function of wavelength from 350 to $700 \mathrm{~nm}$ as seen in Fig. 6. The IPCE values over 50\% were attained for CB2 and CB4 from 350 to $550 \mathrm{~nm}$ with tail off at $700 \mathrm{~nm}$. The dye CB1 and CB3 reached over $40 \%$ in the range of $350-520 \mathrm{~nm}$. The IPCE values of the dyes derived from Fig. 6 are in the order of CB4 > CB2 $>$ CB3 $>$ CB1. Highest IPCE value was observed for the dye CB4, which is due to its broader absorption and better light harvesting capacity in the visible region after adsorbed on the $\mathrm{TiO}_{2}$ surface (Fig. 2). As expected, the trend of IPCE is also in good accordance with $J_{\text {sc }}$ data obtained in $J-V$ measurements.

The DSSC based on the dye N719 under the optimized conditions exhibits the $\eta$ of $7.93 \%$ with a $J_{\mathrm{sc}}$ of $15.34 \mathrm{~mA} \mathrm{~cm}{ }^{-2}$, a $V_{\text {oc }}$ of $718 \mathrm{mV}$ and an FF of 0.72 . Under the same conditions, the DSSCs sensitized with CB1, bearing $N$-octyl carbazole as the donor and linked BODIPY conjugated bridge with 3-position, showed a $J_{\mathrm{sc}}$ of $6.30 \mathrm{~mA} \mathrm{~cm}{ }^{-2}$, a $V_{\mathrm{oc}}$ of $540 \mathrm{mV}$, and an high $\mathrm{FF}$ value of 0.76 , generating an overall conversion efficiency $\eta$ of $2.58 \%$. However, when the $N$-octyl carbazole was replaced with $N$-methoxyphenyl carbazole, the dye $\mathbf{C B} 2$ exhibited a $J_{\mathrm{sc}}$ of 9.18 $\mathrm{mA} \mathrm{cm}{ }^{-2}$, a $V_{\mathrm{oc}}$ of $560 \mathrm{mV}$, an FF of 0.73 , and a $\eta$ of $3.74 \%$. It can be clearly found that the two dyes (CB1 and CB2) show similar $V_{\text {oc }}$ values, but the $J_{\mathrm{sc}}$ increased by about $2.88 \mathrm{~mA} \mathrm{~cm}^{-2}$ for $\mathbf{C B} 2$ with $N$-methoxyphenyl carbazole motif to CB1 with $N$-octyl carbazole unit. The electron-donating $N$-methoxyphenyl groups

Table 2 Photovoltaic parameters of the DSSCs based on CB1-4

\begin{tabular}{lclll}
\hline Dye & $J_{\text {sc }}\left(\mathrm{mA} \mathrm{cm}^{-2}\right)$ & $V_{\text {oc }}(\mathrm{mV})$ & FF & $\eta(\%)$ \\
\hline CB1 & 6.30 & 540 & 0.76 & 2.58 \\
CB2 & 9.18 & 560 & 0.73 & 3.74 \\
CB3 & 6.84 & 540 & 0.73 & 2.68 \\
CB4 & 10.20 & 600 & 0.70 & 4.28 \\
N719 & 15.34 & 718 & 0.72 & 7.93
\end{tabular}


attached on the carbazole donor could reduce the LUMO level of CB2 (as showed in Fig. 4), resulting in an extension of the absorption spectral range to a longer wavelength than that of CB1, which could consequently contribute to an increased lightharvesting efficiency and hence a rise of the $J_{\mathrm{sc}}$ value. The same result was observed in CB3 and CB4. The cell based on CB3 provided a $J_{\mathrm{sc}}$ of $6.84 \mathrm{~mA} \mathrm{~cm}{ }^{-2}$, and a $V_{\mathrm{oc}}$ of $540 \mathrm{mV}$, and an $\eta$ of $2.68 \%$, while the cell sensitized with CB4 presented a higher $J_{\text {sc }}$ of $10.20 \mathrm{~mA} \mathrm{~cm}{ }^{-2}$, a higher $V_{\text {oc }}$ of $600 \mathrm{mV}$ and an overall conversion efficiency $\eta$ of $4.28 \%$, which reached $\sim 54 \%$ of the N719 cell efficiency and are of a high level in the BODIPY based DSSCs. However the PCE is still slightly lower than the similar dye UY11 (4.52\%), reported by Mao et al. ${ }^{30}$ This is due to the fact that U11 with two BODIPY units exhibit a higher $J_{\mathrm{sc}}(11.82 \mathrm{~mA}$ $\mathrm{cm}^{-2}$ ) than $\mathbf{C B} 4$, although $\mathbf{C B} 4$ presentes a higher $V_{\text {oc }}$ value. The results demonstrated that the electron-donating abilities of donors in these dyes significantly effect on the parameters of $J_{\mathrm{sc}}$, and $V_{\text {oc }}$ in their dyes sensitized DSSCs. On the other hand, the substitutional positions also play an important role in the performance of their DSSCs. Compared to CB1 with carbazole donor linked BODIPY at 3-position, the 2-position linked CB3 showed the same $V_{\mathrm{oc}}$ and a similar FF, but a higher $J_{\mathrm{sc}}$ value, leading to a slightly enhancement of $\eta$. Similar observations was also found in CB2 vs. CB4. Benefit for the strong electrondonating donor advantage, along with an appropriate connecting format merit, CB4 sensitized cell displayed the best photovoltaic performance among the four CBs based DSSCs. The excellent device performance also originated in the effective electron injection from photo-excited CB4 to the conduction band of $\mathrm{TiO}_{2}$ film, leading to higher electron injection efficiency, which can be confirmed by IPCE and $J_{\text {sc }}$ values. It worth noting that all these dyes sensitized cells exhibit high FF values, indicating that the special spatial structure of these molecules effectively suppress of excessive dye aggregation on the surface of $\mathrm{TiO}_{2}$.

\subsection{Electrochemical impedance spectroscopy studies}

Electrochemical impedance spectroscopy (EIS) is a powerful technique of characterizing the important interfacial charge transfer processes in a DSSC. The EIS was measured in the dark to elucidate correlation of $V_{\mathrm{oc}}$ with those dyes. The Nyquist plots of DSSCs with CB1-4 are shown in Fig. 8. The small and large semicircles respectively located in the high- and middlefrequency regions, are assigned to the charge transfer at $\mathrm{Pt} /$ electrolyte and $\mathrm{TiO}_{2} /$ dye/electrolyte interface, respectively. ${ }^{53}$ The charge recombination resistance $\left(R_{\text {rec }}\right)$ at the $\mathrm{TiO}_{2}$ surface can be deduced by fitting curves from the range of the middlefrequency using a Z-view software. $R_{\text {rec }}$ is related to the charge recombination rate between injected electron and electron acceptor $\left(\mathrm{I}_{3}{ }^{-}\right)$in the electrolyte, estimated by the large semicircle width. A large $R_{\text {rec }}$ means the small charge recombination rate. The $R_{\text {rec }}$ values for CB4 and CB2 were estimated to be 135 and $117 \Omega$, respectively, which are better than the similar dyes ever reported..$^{30}$ In contrast, CB2 and CB1 were found to have relatively smaller $R_{\text {rec }}$ values at 69 and $56 \Omega$, respectively. The result appears to be consistent with the larger $V_{\text {oc }}$ values for the

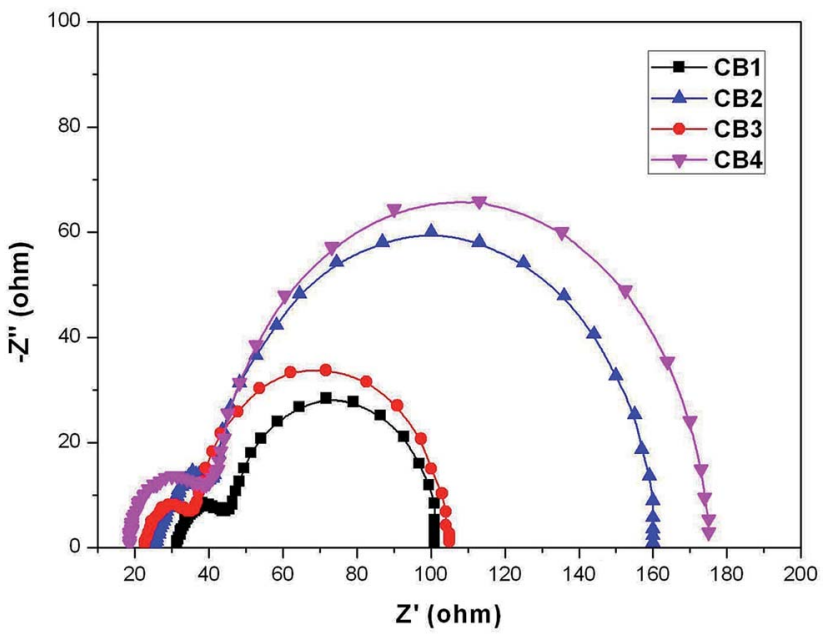

Fig. 8 EIS Nyquist plots for DSSCs based on CB1-4 measured in the dark under $-0.55 \mathrm{~V}$ bias.

dyes CB4 (0.60 V) and CB2 (0.56 V). The significantly increased $R_{\text {rec }}$ values of CB4 and CB2 imply the retardation of the charge recombination between injected electron and $\mathrm{I}_{3}{ }^{-}$ions in the electrolyte, with a consequent increase of $V_{\mathrm{oc}}$.

\section{Conclusions}

In summary, we have synthesized and characterized a series of D- $\pi$-A type organic dyes CB1-4, featuring an $N$-octyl or $N$ methoxyphenyl carbazole as donor with 2 or 3-position substituted at central BODIPY $\pi$-bridge, and cyanoacetic acid as terminal acceptor. The structure-property relationships show that donor's electron-donating abilities, as well as donor's substituted positions have significant influence on the sensitizer's optoelectronic and photovoltaic properties. In comparation with $\mathrm{N}$-octyl carbazole based CB1 and CB3, the $\mathrm{N}$ methoxyphenyl based CB2 and CB4 displayed broader and more intensive absorption both in solution and on the surface of $\mathrm{TiO}_{2}$ due to the extension of $\pi$-conjugated system and enhancement of electron-donating ability, efficiently lead to a decrease of the optical gap by reduce the LUMO energy level. Benefit for these optoelectronic merits, the photovoltaic performances of DSSCs based on CB2 and CB4 are obviously superior to CB1 and CB3 not only in $J_{\mathrm{sc}}$ and $V_{\mathrm{oc}}$ values, but also in the overall conversion efficiency $\eta$. Moreover, the substituted positions of donor also a key factor affect on the device performances. In particular, carbazole 2-position substituted dyes (CB3 and CB4) showed higher $J_{\text {sc }}$ than their carbazole 3-position substituted counterpart (CB1 and CB2). Possessing both of two advantages, CB4 presents the best photovoltaic performance with a $J_{\mathrm{sc}}$ of 10.20 $\mathrm{mA} \mathrm{cm}{ }^{-2}$, an $V_{\mathrm{oc}}$ of $600 \mathrm{mV}$, and FF of 0.7 , corresponding to an $\eta$ of $4.28 \%$ under AM 1.5 irradiation $\left(100 \mathrm{~mW} \mathrm{~cm}^{-2}\right)$, which is an moderate device performance in DSSCs but a fairly good value in BODIPY based DSSCs. The results indicate that well tailored carbazole-BODIPY conjugates are promising candidate for efficient DSSCs. 


\section{Acknowledgements}

We acknowledge the financial support from Characteristic Innovation Program of Guangdong Colleges and Universities (2015KTSCX136), Young Innovative Talents Program of Guangdong Colleges and Universities (2016KQNCX164), Nature Science Foundation of Guangdong Province (2016A030313131, 2016A030313128) and National Nature Science Foundation of China (51476036).

\section{References}

1 B. O'Regan and M. Gratzel, A low-cost, high-efficiency solar cell based on dye-sensitized colloidal $\mathrm{TiO}_{2}$ films, Nature, 1991, 353, 737-740.

2 A. Hagfeldt, G. Boschloo, L. Sun, L. Kloo and H. Pettersson, Dye-sensitized solar cells, Chem. Rev., 2010, 110, 6595-6663.

3 B. E. Hardin, H. J. Snaith and M. D. McGehee, The renaissance of dye-sensitized solar cells, Nat. Photonics, 2012, 6, 162-169.

4 S. Ahmad, E. Guillen, L. Kavan, M. Gratzel and M. K. Nazeeruddin, Metal free sensitizer and catalyst for dye sensitized solar cells, Energy Environ. Sci., 2013, 6, 3439-3466.

5 A. Yella, H. W. Lee, H. N. Tsao, C. Y. Yi, A. K. Chandiran, M. K. Nazeeruddin, et al., Porphyrin-sensitized solar cells with cobalt(II/III)-based redox electrolyte exceed 12 percent efficiency, Science, 2011, 334, 629-634.

6 A. Yella, C. Mai, S. M. Zakeeruddin, S. Chang, C. Hsieh, C. Yeh, et al., Molecular engineering of push-pull porphyrin dyes for highly efficient dye-sensitized solar cells: the role of benzene spacers, Angew. Chem., Int. Ed., 2014, 53, 2973-2977.

7 S. Mathew, A. Yella, P. Gao, R. Humphry-Baker, F. E. CurchodBasile, N. Ashari-Astani, et al., Dye- sensitized solar cells with $13 \%$ efficiency achieved through the molecular engineering of porphyrin sensitizers, Nat. Chem., 2014, 6, 242-247.

8 M. Mishra, M. Fischer and P. Bäuerle, Metal-free organic dyes for dye-sensitized solar cells: from structure: property relationships to design rules, Angew. Chem., Int. Ed., 2009, 48, 2474-2499.

9 H. Imahori, T. Umeyama and S. Ito, Large $\pi$-aromatic molecules as potential sensitizers for highly efficient dyesensitized solar cells, Acc. Chem. Res., 2009, 42, 1809-1818.

10 M. Urbani, M. Grätzel, M. K. Nazeeruddin and T. Torres, Meso-substituted porphyrins for dye-sensitized solar cells, Chem. Rev., 2014, 114, 12330-12396.

11 T. Higashino and H. Imahori, Porphyrins as excellent dyes for dye-sensitized solar cells: recent developments and insights, Dalton Trans., 2015, 44, 448-463.

12 G. Copley, D. Hwang, D. Kim and A. Osuka, First-generation subporphyrinatoboron(III) sensitizers surpass the $10 \%$ power conversion efficiency threshold, Angew. Chem., Int. Ed., 2016, 55, 10287-10291.

13 D. P. Hagberg, J. H. Yum, H. Lee, F. De Angelis, T. Marinado, K. M. Karlsson, et al., Molecular engineering of organic sensitizers for dye-sensitized solar cell applications, J. Am. Chem. Soc., 2008, 130, 6259-6266.

14 W. Zeng, Y. Cao, Y. Bai, Y. Wang, Y. Shi, M. Zhang, et al., Efficient dye-sensitized solar cells with an organic photosensitizer featuring orderly conjugated ethylenedioxythiophene and dithienosilole blocks, Chem. Mater., 2010, 22, 1915-1925.

15 J. Y. Mao, N. N. He, Z. J. Ning, Q. Zhang, F. L. Guo, L. Chen, et al., Stable dyes containing double acceptors without $\mathrm{COOH}$ as anchors for highly efficient dye-sensitized solar cells, Angew. Chem., Int. Ed., 2012, 51(9), 873-876.

16 Y. J. Chang, Y.-J. Wu, P.-T. Chou, M. Watanabe and T. J. Chow, Triarylene linked spacer effect for dyesensitized solar cells, Thin Solid Films, 2014, 558, 330-336.

17 A. Diac, D. Demeter, S. Jungsuttiwong, I. Grosu and J. Roncali, ADDA and ADADA systems based on triphenylamine as molecular donors for organic photovoltaics, Tetrahedron Lett., 2015, 56, 4607-4612.

18 D. Demeter, J. Roncali, S. Jungsuttiwong, F. Melchiorre, P. Biagini and R. Po, Linearly $\pi$-conjugated oligothiophenes as simple metal-free sensitizers for dyesensitized solar cells, J. Mater. Chem. C, 2015, 3, 77567761.

19 K. Hara, T. Sato, R. Katoh, A. Furube, Y. Ohga, A. Shinpo, et al., Molecular design of coumarin dyes for efficient dyesensitized solar cells, J. Phys. Chem. B, 2003, 107, 597-606.

20 K. D. Seo, I. T. Choi, Y. G. Park, S. Kang, J. Y. Lee and H. K. Kim, Novel D-A- $\pi-\mathrm{A}$ coumarin dyes containing low band-gap chromophores for dye-sensitised solar cells, Dyes Pigm., 2012, 94, 469-474.

21 J. Yang, P. Ganesan, J. Teuscher, T. Moehl, Y. J. Kim, C. Yi, et al., Influence of the donor size in $\mathrm{D}-\pi-\mathrm{A}$ organic dyes for dye-sensitized solar cells, J. Am. Chem. Soc., 2014, 136, 5722-5730.

22 T. Horiuchi, H. Miura and S. Uchida, Highly-efficient metalfree organic dyes for dye-sensitized solar cells, Chem. Commun., 2003, 24, 3036-3037.

23 A. S. Hart, K. C. Cb, N. K. Subbaiyan, P. A. Karr and F. D'Souza, Phenothiazine-sensitized organic solar cells: effect of dye anchor group positioning on the cell performance, ACS Appl. Mater. Interfaces, 2012, 4, 5813-5820.

24 Z.-S. Huang, H. Meier and D. Cao, Phenothiazine-based dyes for efficient dyesensitized solar cells, J. Mater. Chem. C, 2016, 4, 2404-2426.

25 T. Papalia, R. Lappano, A. Barattucci, A. Pisano, G. Bruno, M. F. Santolla, et al., A bodipy as a luminescent probe for detection of the $\mathrm{G}$ protein estrogen receptor (GPER), Org. Biomol. Chem., 2015, 13, 10437-10441.

26 G. Ulrich, R. Ziessel and A. Harriman, The chemistry of fluorescent bodipy dyes: versatility unsurpassed, Angew. Chem., Int. Ed., 2008, 47, 1184-1201.

27 A. Kamkaew, S. H. Lim, H. B. Lee, L. V. Kiew, L. Y. Chung and K. Burgess, BODIPY dyes in photodynamic therapy, Chem. Soc. Rev., 2013, 42, 77-88.

28 M. Mao, J. B. Wang, Z. F. Xiao, S. Y. Dai and Q. H. Song, New 2,6-modified BODIPY sensitizers for dye-sensitized solar cells, Dyes Pigm., 2012, 94, 224-232. 
29 J. F. Lefebvre, X. Z. Sun, J. A. Calladine, M. W. George and E. A. Gibson, Promoting charge-separation in p-type dyesensitized solar cells using bodipy, Chem. Commun., 2014, 50, 5258-5260.

30 M. Mao, X. Zhang, L. Cao, Y. Tonf and G. Wu, Design of Bodipy based organic dyes for high-efficient dye-sensitized solar cells employing double electron acceptors, Dyes Pigm., 2015, 117, 28-36.

31 Y. Kubo, D. Eguchi, A. Matsumoto, R. Nishiyabu, H. Yakushiji, K. Shigaki, et al., Borondiberonzopyrromethene-based organic dyes for application in dye-sensitized solar cells, J. Mater. Chem. A, 2014, 2, 5204-5211.

32 J. B. Wang, X. Q. Fang, X. Pan, S. Y. Dai and Q. H. Song, New 2,6-modified BODIPY sensitizers for dye-sensitized solar cells, Chem.-Asian J., 2012, 7, 696-700.

33 M. Mao, X. L. Zhang, X. Q. Fang, G. H. Wu, Y. Ding, X. L. Liu, et al., 2,6-Conjugated Bodipy sensitizers for highperformance dye-sensitized solar cells, Org. Electron., 2014, 15, 2079-2090.

34 Z.-S. Wang, N. Koumura, Y. Cui, M. Takahashi, H. Sekiguchi, A. Mori, et al., Hexylthiophene-functionalized carbazole dyes for efficient molecular photovoltaics: tuning of solar-cell performance by structural modification, Chem. Mater., 2008, 20, 3993-4003.

35 R. R. Reghu, H. K. Bisoyi, J. V. Grazulevicius, P. Anjukandi, V. Gaidelis and V. Jankauskas, Air stable electrontransporting and ambipolar bay substituted perylene bisimides, J. Mater. Chem., 2011, 21, 7811-7819.

36 H. Zhang, Q. Cai and D. Ma, Amino acid promoted CuIcatalyzed $\mathrm{C}-\mathrm{N}$ bond formation between aryl halides and amines or N-containing heterocycles, J. Org. Chem., 2005, 70, 5164-5173.

37 P. Zhou, D. Dang, Q. Wang, X. Duan, M. Xiao, Q. Tao, et al., Enhancing the photovoltaic performance of triphenylamine based star-shaped molecules by tuning the moiety sequence of their arms in organic solar cells, J. Mater. Chem. A, 2015, 3, 13568-13576.

38 M. J. Ortiz, A. R. Agarrabeitia, G. Duran-Sampedro, J. Prieto, T. A. Lopez, W. A. Massad, et al., Synthesis and functionalization of new polyhalogenated BODIPY dyes. Study of their photophysical properties and singlet oxygen generation, Tetrahedron, 2012, 68, 1153-1162.

39 K. Kalyanasundaram and M. Grätzel, Applications of functionalized transition metal complexes in photonic and optoelectronic devices, Coord. Chem. Rev., 1998, 177, 347414.

40 G. R. A. Kumara, S. Kaneko, A. Konno, M. Okuya and K. Murakami, Large area dye-sensitized solar cells: material aspects of fabrication, Prog. Photovoltaics, 2006, 14, 643-651.

41 J. Liao, H. Zhao, Y. Xu, Z. Cai, Z. Peng, W. Zhang, et al., Novel D-A-D type dyes based on BODIPY platform for solution processed organic solar cells, Dyes Pigm., 2016, 128, 131-140.

42 J. Liao, Y. Xu, H. Zhao, Y. Wang, W. Zhang, F. Peng, et al., Synthesis, optical, electrochemical properties and photovoltaic performance of novel panchromatic mesothiophene BODIPY dyes with a variety of electron-donating groups at the 3,5-positions, RSC Adv., 2015, 5, 86453-86462.

43 A. Loudet and K. Burgess, BODIPY Dyes and their derivatives: syntheses and spectroscopic properties, Chem. Rev., 2007, 107, 4891-4932.

44 P. Wang, B. Wenger, R. Humphry-Baker, J.-E. Moser, J. Teuscher, W. Kantlehner, et al., Charge separation and efficient light energy conversion in sensitized mesoscopic solar cells based on binary ionic liquids, J. Am. Chem. Soc., 2005, 127, 6850-6856.

45 C.-J. Yang, Y. Chang, M. Watanabe, Y.-S. Hon and T. Chow, Phenothiazine derivatives as organic sensitizers for highly efficient dye-sensitized solar cells, J. Mater. Chem., 2012, 22, 4040-4049.

46 P. Shen, X.-P. Liu, S.-H. Jiang, Y.-S. Huang, L. Yi, B. Zhao, et al., Effects of aromatic $\pi$-conjugated bridges on optical and photovoltaic properties of $N, N$-diphenylhydrazonebased metal-free organic dyes, Org. Electron., 2011, 12, 1992-2002.

47 M. Gratzel, Photoelectrochemical cells, Nature, 2001, 414, 338-344.

48 P. Wang, S. Zakeeruddin, J. Moser and M. A. Gratzel, New ionic liquid electrolyte enhances the conversion efficiency of dye-sensitized solar cells, J. Phys. Chem. B, 2003, 107, 13280-13285.

49 M. J. Frisch, G. W. Trucks, H. B. Schlegel, G. E. Scuseria, M. A. Robb and J. R. Cheeseman, et al., Gaussian 09, revision C.01, Gaussian Inc, Wallingford, CT, 2009.

50 M. Liang and J. Chen, Arylamine organic dyes for dyesensitized solar cells, Chem. Soc. Rev., 2013, 31, 125-132.

51 J. G. Chen, C. Y. Chen, S. J. Wu, J. Y. Li, C. G. Wu and K. C. Ho, On the photophysical and electrochemical studies of dye-sensitized solar cells with the new dye CYCB1, Sol. Energy Mater. Sol. Cells, 2008, 92, 1723-1727.

52 L. Y. Lin, C. P. Lee, M. H. Yeh, A. Baheti, R. Vittal, K. R. J. Thomas, et al., A novel 2,7-diaminofluorene-based organic dye for a dye-sensitized solar cell, J. Power Sources, 2012, 215, 122-129.

53 C. Longo, A. F. Nogueira, M.-A. De Paoli and H. Cachet, Solid-State and flexible dye-sensitized $\mathrm{TiO}_{2}$ solar cells: a study by electrochemical impedance spectroscopy, $J$. Phys. Chem. B, 2002, 106, 5925-5930. 